\title{
Victims or vectors: a survey of marine vertebrate zoonoses from coastal waters of the Northwest Atlantic
}

\author{
Andrea L. Bogomolni ${ }^{1}$, Rebecca J. Gast ${ }^{1}$, Julie C. Ellis ${ }^{2}$, Mark Dennett ${ }^{1}$, \\ Katie R. Pugliares ${ }^{3}$, Betty J. Lentell ${ }^{4}$, Michael J. Moore ${ }^{1, *}$ \\ ${ }^{1}$ Biology Department, Woods Hole Oceanographic Institution, Woods Hole, Massachusetts 02543, USA \\ ${ }^{2}$ Tufts University, Cummings School of Veterinary Medicine, 200 Westboro Road, North Grafton, Massachusetts 01536, USA \\ ${ }^{3}$ Cape Cod Stranding Network, a project of IFAW, 290 Summer Street, Yarmouthport, Massachusetts 02675, USA \\ ${ }^{4}$ National Marine Fisheries Service, Northeast Fisheries Observer Program, 166 Water Street, Woods Hole, \\ Massachusetts 02543, USA
}

\begin{abstract}
Surveillance of zoonotic pathogens in marine birds and mammals in the Northwest Atlantic revealed a diversity of zoonotic agents. We found amplicons to sequences from Brucella spp., Leptospira spp., Giardia spp. and Cryptosporidium spp. in both marine mammals and birds. Avian influenza was detected in a harp seal and a herring gull. Routine aerobic and anaerobic culture showed a broad range of bacteria resistant to multiple antibiotics. Of 1460 isolates, 797 were tested for resistance, and 468 were resistant to one or more anti-microbials. $73 \%(341 / 468)$ were resistant to 1-4 drugs and $27 \%(128 / 468)$ resistant to 5-13 drugs. The high prevalence of resistance suggests that many of these isolates could have been acquired from medical and agricultural sources and inter-microbial gene transfer. Combining birds and mammals, 45\% (63/141) of stranded and $8 \%$ $(2 / 26)$ of by-caught animals in this study exhibited histopathological and/or gross pathological findings associated with the presence of these pathogens. Our findings indicate that marine mammals and birds in the Northwest Atlantic are reservoirs for potentially zoonotic pathogens, which they may transmit to beachgoers, fishermen and wildlife health personnel. Conversely, zoonotic pathogens found in marine vertebrates may have been acquired via contamination of coastal waters by sewage, run-off and agricultural and medical waste. In either case these animals are not limited by political boundaries and are therefore important indicators of regional and global ocean health.
\end{abstract}

KEY WORDS: Zoonosis $\cdot$ Vertebrate $\cdot$ Northwest Atlantic $\cdot$ Pinniped $\cdot$ Cetacean $\cdot$ Bird

\section{INTRODUCTION}

As human populations in coastal areas continue to increase, coastal ecosystems may become increasingly important as reservoirs or sentinels of infectious organisms from agricultural, animal and human waste. Resultant human and wildlife disease outbreaks and mortality events that occur in the marine environment can increase awareness of the connection between diverse taxa, terrestrial ecosystems, ocean and human health and the risk of infection with zoonotic diseases.
Better understanding of the ecology of infectious diseases of multiple taxa of marine animals, which share marine resources and pathogens, will allow for better prediction of the risks to human health. Influences driving the risk of zoonotic infection may include (1) changes in human activity, such as agriculture, (2) increased population density in coastal communities, (3) waste management, (4) consumption of wildlife and (5) changes in medical technology (Hauschild \& Gauvreau 1985, Myers et al. 1993, Graczyk et al. 1997, Woolhouse \& Gowtage-Sequeria 2005). Thus human 
activity is resulting in a marine environment in which pathogens, including protozoa, can thrive (Johnson et al. 1997, 1998, Fayer 2004, Boinapally \& Jiang 2007).

Infectious diseases can substantially alter long-term trends in populations, including wildlife, or result in short-term reductions in local abundance (Heide-Jørgensen et al. 1992). Pathogens, in combination with a weakened population, habitat loss, increased predation, climate change and anthropogenic pollution can also result in severe disease outbreaks which can ultimately lead to extinction of species (Warner 1968, Pounds et al. 2006). Throughout history, there have been numerous opportunities for the introduction of a pathogen to new hosts and the spread to new host populations (Morse 1993, Dobson \& Carper 1996, Daszak et al. 2001, Wolfe et al. 2007). Some of the most novel human viruses are zoonotic: the source of these pathogens include the marine environment (Jones et al. 2008), which lacks the barriers inherent in terrestrial dispersal (Morse 1993, McCallum et al. 2003). In the case of West Nile Virus, the spread of the virus occurred along the Atlantic seaboard, a common migration route for many bird species in the Northeastern Seaboard of North America (Rappole et al. 2000). Similarly, the spread of influenza A from aquatic birds is believed to be the most probable source of all influenza A virus strains in other species as was the case in the 1982 mortality event affecting harbor seals in the northeast USA (Hinshaw et al. 1984, Callan et al. 1995, Webster 1998, Horimoto \& Kawaoka 2001).

Marine vertebrates are no exception to the role of host, and host population, in an environment where for some, diseases are increasing (Harvell et al. 1999, Daszak et al. 2001, Lafferty et al. 2004). The northeast USA has experienced several epizootic events resulting in mass mortalities of marine mammals and seabirds caused by a variety of viral, bacterial, parasitic, and toxic agents. These events include the 1979-1980 influenza A mortality event and the 1991-1992 phocine distemper morbillivirus (PDV) event in harbor seals Phoca vitulina of New England (Geraci et al. 1982, Duignan et al. 1995). Mass die-offs of birds have been attributed to the introduction and spread of West Nile Virus between 1999 and 2000 in New York State (Bernard et al. 2001). The largest recorded common tern Sterna hirundo mortality event in the National Wildlife Health Center epizootic database was attributed to Salmonella typhimurium at the Monomoy National Wildlife Refuge, Massachusetts (Sohn et al. 2004). Acanthocephalan enteritis has been described in common eiders Somateria mollissima in Massachusetts (Clark et al. 1958), with a recent undiagnosed mortality in Wellfleet, Massachusetts involving over 2400 birds (Jankowsky et al. 2007). A mass mortality of humpback whales in 1987 was attributed to saxitoxin ingestion (Geraci et al. 1989).
Mass beach mortalities of charismatic marine macrofauna garner the attention of many; however, it is the underlying potential for the presence and spread of disease that motivated our regional monitoring of zoonotic pathogens. Increases in human population in coastal communities, human-wildlife interactions, and recognition of the economic as well as social importance of the marine environment of the Northeast US region, contributed to our interest in assessing the prevalence of disease causing microbes. In this study we surveyed a broad cross-section of available hosts within subsets of populations that included live, stranded and fishery by-caught marine vertebrates. These animals were surveyed for bacterial, protozoan and viral pathogens. The specific pathogens targeted were those known to be prevalent in one or more of the vertebrates studied locally or elsewhere in the world. Resource limitation precluded a fully comprehensive survey of all potential zoonotic agents.

\section{MATERIALS AND METHODS}

Sample collection. Stranded and by-caught mortality samples: Stranded and by-caught birds were collected by the staff at the Seabird Ecological Assessment Network (SEANET, www.tufts.edu/vet/seanet/), Massachusetts Audubon Society, National Oceanographic Atmospheric Administration (NOAA) Northeast Fisheries Science Center (NEFSC) Observer Program and the authors. Marine mammals were collected with the assistance of the New England Aquarium, University of New England Marine Animal Rehabilitation Center, the NOAA NEFSC Observer Program and the authors. Large whale cases were necropsied at the site of stranding (usually beach), and a subset of birds were frozen and then thawed before sampling. Other animals were necropsied in a laboratory between 4 and $48 \mathrm{~h}$ post mortem (stored at $4^{\circ} \mathrm{C}$ overnight). Full necropsies of marine mammals were conducted under protocols described by Pugliares et al. (2007). Necropsies of marine birds were conducted using protocols as described by SEANET www.tufts.edu/ vet/seanet. Tissue samples and data are archived at WHOI and Tufts University. Tissue samples were collected using equipment sterilized by rinsing with $95 \%$ ethanol followed by flaming with a butane torch.

Live animal samples: Fecal samples were collected from live-caught gulls at Kent Island, Canada, Appledore Island, Maine, and Monomoy National Wildlife Refuge, Massachusetts. Adult great black-backed gulls Larus marinus, herring gulls L. argentatus, and laughing gulls L. atricilla were captured during egg incubation using chicken wire walk-in nest or drop- 
down traps. Each bird was banded, measured, and pharyngeal and cloacal swabs were collected to obtain samples of bacteria. A fresh sample of feces was also collected from each bird by placing it into a plastic box for $<1$ min just prior to releasing it; most birds responded to box placement by voiding their cloacas almost immediately. Fecal samples were transferred to sterile cryovials using plastic sterile Pasteur pipettes or syringes. The liner at the bottom of the box was replaced between each bird, so as to avoid contamination. Fecal samples were used for analyses of parasites and bacteria. Pharyngeal swabs were used for analyses of bacteria and influenza. Avian pharyngeal rather than the commonly used fecal swabs were used to allow direct comparability with mammalian nasal swabs.

Fecal samples from seals and birds were collected from beaches in the USA at the Isles of Shoals, New Hampshire, Maine; Great Island in Wellfleet, Massachusetts; Muskeget Island, Nantucket Sound, Massachusetts; Monomoy National Widlife Refuge; and Chatham Harbor, Chatham, Massachusetts. Visual identifications and photographs of the species present at each beach were made before approaching the animals and collecting feces. Animals were identified as harbor seal Phoca vitulina, grey seal Halichoerus gryphus, double-crested cormorant Phalacrocorax auritus, and herring and great black-backed gulls. If a seal haul out site was not $>90 \%$ of one species, samples were recognized as a mix of the species present (i.e. grey/harbor seal). Bacterial swabs of feces were taken on site. Samples of 1 to $10 \mathrm{~g}$ were placed on ice in sterile cryovials for molecular analysis and frozen at $-70^{\circ} \mathrm{C}$ on return to the laboratory. Samples for aerobic and anaerobic bacteria were collected using Fisherfinest ${ }^{\mathrm{TM}}$ Amies clear gel transport swabs (Fisher Scientific) and submitted within 24 h to IDEXX Laboratories, Grafton, Massachusetts.

Pathogen determination. DNA isolation: Nucleic acids were extracted from tissue samples using the QIAGEN Tissue Kit and from fecal samples using the Mo Bio Soil Kit (Mo Bio Laboratories) following the kit instructions. Urine samples were extracted using the Mo Bio Soil Kit, but with the urine as a volume with weight equal to $250 \mu \mathrm{g}$. Samples tested include liver, lung, tracheo-bronchial lymph, spleen, kidney, testes, ovary, uterus, urine, bursa, gut content, feces and brain.

PCR detection: Samples collected from the environment often contain agents that inhibit amplification, so each sample was tested to ensure that it was competent for PCR amplification by using primers flanking a highly conserved fragment of the 18S rRNA gene. All samples that generated a product of the correct size were then tested for human pathogen DNA. In some samples which exhibited amplification inhibition, a 1:10 dilution of the sample eliminated the inhibition and resulted in a product. In these cases, the 1:10 dilution was used for further analysis. All PCR experiments had positive controls for corresponding parasite/ pathogen DNA (10 ng per $50 \mu$ reaction) and negative controls for contamination without added template DNA. All PCR reactions were run on agarose gels for detection of products, using a $2 \%$ gel for the Giardia products, but a $1 \%$ gel for all the others.

Brucella spp. and Leptospira spp. screening: Only tissue samples and urine were tested routinely for Leptospira spp. and Brucella spp. Leptospira spp. were detected using the Lep1/Lep2 16S rDNA primer set (Merien et al. 1992) and the cycling protocol $94^{\circ} \mathrm{C}$ (3 min), followed by 40 cycles of $94^{\circ} \mathrm{C}(1 \mathrm{~min}), 60^{\circ} \mathrm{C}$ $(1 \mathrm{~min}), 72^{\circ} \mathrm{C}(1.5 \mathrm{~min})$, with a final extension of $72^{\circ} \mathrm{C}$ (10 $\mathrm{min})$ to produce an approximately $330 \mathrm{bp}$ amplicon. Brucella spp. were detected using the Bru4/Bru5 $31 \mathrm{kDa}$ outer membrane protein primer set described in Bailey et al. (1992) to produce an amplicon of approximately $220 \mathrm{bp}$. The cycling protocol was $93^{\circ} \mathrm{C}$ (5 min), followed by 40 cycles of $94^{\circ} \mathrm{C}(1 \mathrm{~min}), 62^{\circ} \mathrm{C}$ $(1 \mathrm{~min}), 72^{\circ} \mathrm{C}(1 \mathrm{~min})$, and a final extension of $72^{\circ} \mathrm{C}$ (10 $\mathrm{min})$. On the first 30 necropsies, frozen tissue samples for Brucella spp. determination were sent for culture to the US Department of Agriculture (USDA at Ames, Iowa. Frozen tissues were sent to the Oklahoma State Animal Disease Diagnostic Laboratory (OADDL), Stillwater, Oklahoma for determination of Leptospira interrogans by PCR (Acevedo-Whitehouse et al. 2003). Some Leptospira and Brucella amplicons were sequenced to confirm amplification of the correct targets.

Giardia and Cryptosporidium screening: The primer set used most extensively to detect Giardia spp. (GGL639/GGR789) targets a $171 \mathrm{bp}$ fragment of the giardin gene (Mahbubani et al. 1992). These primers were applied in a nested amplification protocol that used $1 \mu \mathrm{l}$ of the first reaction as template for the second, and each reaction had a total volume of $25 \mu \mathrm{l}$. Amplification parameters were $94^{\circ} \mathrm{C}(2 \mathrm{~min})$, followed by $94^{\circ} \mathrm{C}(30 \mathrm{~s}), 56^{\circ} \mathrm{C}(30 \mathrm{~s}), 72^{\circ} \mathrm{C}(1 \mathrm{~min})$, and a hold at $4^{\circ} \mathrm{C}$. The first amplification was carried out for 25 cycles, and the second amplification was 40 cycles. Samples positive by Giardia genus amplification were tested for Giardia intestinalis using the primer set MAH433F/MAH592R (Rochelle et al. 1997), with cycling parameters $94^{\circ} \mathrm{C}(4 \mathrm{~min})$, followed by $94^{\circ} \mathrm{C}$ $(1 \mathrm{~min}), 60^{\circ} \mathrm{C}(1 \mathrm{~min}), 72^{\circ} \mathrm{C}(1 \mathrm{~min})$, and a hold at $4^{\circ} \mathrm{C}$. Again a nested amplification strategy was applied, with the first using 25 cycles and the second using 40 cycles. Reactions were a total volume of $25 \mu \mathrm{l}$ each. Our samples positive for the Giardia genus were genotyped by our collaborators (Lasek-Nesselquist et al. 2008, this issue). 
The PCR primers used for Cryptosporidium 18S rDNA detection were the nested set WR494F/AWA 1206R and CPB DiagF/PW99R (Ward et al. 2002), resulting in an amplicon of approximately $420 \mathrm{bp}$. The nested protocol used $25 \mu \mathrm{l}$ reactions and cycling parameters of $94^{\circ} \mathrm{C}(10 \mathrm{~min})$, followed by 40 cycles of $94^{\circ} \mathrm{C}$ $(30 \mathrm{~s}), 58^{\circ} \mathrm{C}(40 \mathrm{~s}), 72^{\circ} \mathrm{C}(40 \mathrm{~s})$, and a hold at $4^{\circ} \mathrm{C}$. One microliter of the first reaction was used as template for the second reaction with the same cycling parameters. Samples positive using the genus primers were tested for Cryptosporidium parvum using the primer sets Cry5/Cry6 and NCryp1/NCryp2 described previously (Mayer \& Palmer 1996). The first reaction was $94^{\circ} \mathrm{C}$ (2 min), followed by 35 cycles of $94^{\circ} \mathrm{C}(30 \mathrm{~s}), 56^{\circ} \mathrm{C}$ (30 s), and a final extension at $72^{\circ} \mathrm{C}(1 \mathrm{~min})$. The second reaction was $94^{\circ} \mathrm{C}(2 \mathrm{~min})$, followed by 40 cycles of $94^{\circ} \mathrm{C}(30 \mathrm{~s}), 60^{\circ} \mathrm{C}(30 \mathrm{~s}), 72^{\circ} \mathrm{C}(30 \mathrm{~s})$, and a final extension at $72^{\circ} \mathrm{C}$ (3.5 min). Some Giardia and Cryptosporidium amplicons were sequenced to confirm correct target amplification.

Bacterial culture with antibiotic sensitivity: Routine sampling sites included fecal/cloaca swabs for live animals, thorax (using an intercostal approach to the pleural space) and abdomen or coelom (using a lateral abdominal approach to the peritoneal space) for those examined by necropsy. Thorax and abdomen/coelom sample sites were flame seared and incised with a sterile blade. Swabs from nasal/blowhole/nares were collected as appropriate and practical on live animals and if contamination of the outside surface of dead animals was minimal. Other sites were chosen for bacterial isolation if lesions or infection were suspected. Cultures for fungal agents were only submitted if suspected at gross necropsy. All samples were collected using sterile methods. Swabs were shipped overnight to IDEXX Laboratories (Grafton, Massachusetts) and plated on blood agar, and MacConkey plates for aerobic culture, and blood agar, MacConkey and anaerobic blood agar plates for anaerobic culture.

Anaerobic and anaerobic bacteria were recovered, identified and aerobic bacteria were tested for antibiotic sensitivity using the Vitek system (bioMérieux Vitek). Requests were made for culture to include Campylobacter and Salmonella for fecal swabs. All others were requested for routine cultures. No growth was assumed after $48 \mathrm{~h}$ of negative culture. Antibiotics tested routinely included amikacin (AMK), ampicillin (AMP), augmentin (amoxicillin + clavulanic acid, AUG), carbenicillin (CAR), ceftazidime (CAZ), ceftiofur (CEF), cephalothin (CEPH), cloramphenicol (CHL), ciprofloxacin (CIP), gentamycin (GEN), tribrissen (TRI), piperacillin (PIP), enrofloxacin (ENR), tetracycline (TET), ticarcillin (TIC), and tobramycin (TOB). Penicillin G (PENG), vancomycin (VAN), oxacillin (OX) and erythromycin (ERY) were tested only with the following bacteria: Enterococcus spp. were only tested for AMP, CHL, TET, PENG, and VANC sensitivity; and Staphylococcus spp. were only tested for AUG, AMP, CEF, ENR, GEN, TET, OX, PENG and VANC sensitivity. Multiple antibiotic resistance (MAR) indices (Kruperman 1983) were calculated for each isolate, and ranged from 0 to 1.

Influenza virus isolation: Viral swabs of lung and nasal/blow/nares were placed in viral media (Hardy Diagnostics). Viral samples for molecular and culture analysis were frozen at $-70^{\circ} \mathrm{C}$ and sent to the United States Geological Survey (USGS) National Wildlife Health Laboratory (NWHL), Madison, Wisconsin, for influenza A and B type analysis. Each sample was tested by RNA extraction and by the Matrix RT-PCR test for avian influenza. Influenza B was tested using the BD Directigen Flu A/B test (BD, Franklin Lakes, New Jersey). Additional diagnostic tests on a random selection of $25 \mathrm{oral} / \mathrm{nasal} / \mathrm{blow}$ samples were tested using the Remel XPECT ${ }^{\mathrm{TM}}$ FLU A\&B Test Kit (Remel) for influenza A and B identification.

Histopathology: Histopathology samples were fixed in $10 \%$ neutral buffered formalin, dehydrated and embedded in paraffin and sectioned for examination of $5 \mu \mathrm{m}$ hematoxylin-and-eosin stained slides by Northwest ZooPath (Monroe, Washington) and the University of Tennessee, College of Veterinary Medicine (Knoxville, Tennessee).

Gross and histopathology analysis: Using histopathology, gross pathology and molecular results, each case was categorized into 1 of 14 categories of significant findings: (1) bycatch with no significant findings (NSF), (2) bycatch with gas emboli/bubbles, (3) bycatch with disease process, (4) bycatch other, (5) could not be determined (CBD), (6) emaciation, (7) infectious disease (bacterial/viral/fungal), (8) human interaction, (9) mass stranding NSF, (10) neurological, (11) other, (12) parasitism, (13) predation, and (14) tournament caught. We did not analyze by cause of death given the presence of significant pathology in some by-caught animals. Where an animal could fall into 2 categories, the category that most specifically described the gross and histopathological findings was chosen.

\section{RESULTS}

Between December 2005 and August 2007 a total of 370 live, stranded, fishery by-caught and tournamentcaught marine vertebrates were sampled: 165 individuals of 15 species of marine mammals, 192 individuals of 15 species of seabird, and 13 individuals of 3 species of shark (Table 1). Geographic ranges of the animals collected extended north to Kent Island, Canada $\left(44.58^{\circ} \mathrm{N}, 66.75^{\circ} \mathrm{W}\right)$ and south to Virginia, USA 
Table 1. Individual marine vertebrate species surveyed for zoonoses. Values are numbers of individuals

\begin{tabular}{|c|c|c|c|c|c|}
\hline Species & Common name & By-caught & Live & Stranded & Total \\
\hline Marine mammals & & & & & 165 \\
\hline Balaenoptera acutorostrata & Minke whale & & & 2 & \\
\hline Cystophora cristata & Hooded seal & & & 1 & \\
\hline Delphinus delphis & Short-beaked common dolphin & 1 & & 16 & \\
\hline Globicephala melas & Long-finned pilot whale & & & 2 & \\
\hline Grampus griseus & Risso's dolphin & & & 2 & \\
\hline Halichoerus grypus & Grey seal & 5 & 58 & 2 & \\
\hline Kogia breviceps & Pygmy sperm whale & & & 2 & \\
\hline Lagenorhynchus acutus & Atlantic white-sided dolphin & 1 & & 4 & \\
\hline Megaptera novaeangliae & Humpback whale & & & 1 & \\
\hline Phoca groenlandica & Harp seal & 5 & & 7 & \\
\hline Phoca vitulina & Harbor seal & 3 & 12 & 2 & \\
\hline Phocoena phocoena & Harbor porpoise & 7 & & 1 & \\
\hline Stenella coeruleoalba & Striped dolphin & & & 1 & \\
\hline Mixed haul out ${ }^{\mathrm{a}}$ & Grey or harbor seal & & 28 & & \\
\hline Unidentified delphinid & Unidentified delphinid & & & 1 & \\
\hline Ziphius cavirostris & Cuvier's beaked whale & & & 1 & \\
\hline Seabirds & & & & & 192 \\
\hline Charadrius melodus & Piping plover & & & 2 & \\
\hline Somateria mollissima & Common eider & & & 47 & \\
\hline Gavia immer & Common loon & & & 9 & \\
\hline Sterna hirundo & Common tern & & & 1 & \\
\hline Larus marinus & Great black-backed gull & & 17 & 9 & \\
\hline Phalacrocorax carbo & Great cormorant & & & 3 & \\
\hline Puffinus gravis & Greater shearwater & 3 & & 1 & \\
\hline Larus argentatus & Herring gull & & 64 & 12 & \\
\hline Larus atricilla & Laughing gull & & 4 & & \\
\hline Sternula antillarum & Least tern & & & 2 & \\
\hline Moras Bassanus & Northern gannet & & & 6 & \\
\hline Phalacrocorax auritus & Double crested cormorant & 1 & 6 & 1 & \\
\hline Gavia stellata & Red throated loon & 1 & & 1 & \\
\hline Melanitta perspicillata & Surf scoter & & & 1 & \\
\hline Melanitta deglandi & White winged scoter & & & 1 & \\
\hline Sharks & & & & & 13 \\
\hline Aliopias vulpinus & Thresher shark & 9 & & & \\
\hline Isurus paucus & Mako shark & 3 & & & \\
\hline Prionace glauca & Blue shark & 1 & & & \\
\hline Total & & 40 & 189 & 141 & 370 \\
\hline
\end{tabular}

$\left(38.82^{\circ} \mathrm{N}, 75.95^{\circ} \mathrm{W}\right)$ (Fig. 1). Of the total stranded and by-caught animals, 167 cases were examined by gross necropsy including 96 stranded birds, 45 stranded marine mammals, 22 by-caught marine mammals and 4 by-caught birds. Individual species sample sizes are mostly too small for statistical tests, but the findings are relevant for the identification of host species and situations requiring further study.

\section{Molecular screening results}

A total of 635 samples were analyzed from 236 animals (Table 2). Amplification of Brucella spp. was conducted in 109 animals. Positive tissues were found in 38 animals within 16 species of stranded and bycaught birds, dolphins, seals, and whales. Species included hooded seal Cystophora cristata, harp seal Phoca groenlandica, grey seal Halichoerus grypus, an unidentified delphinid species, common dolphin Delphinus delphis, long-finned pilot whale Globicephala melas, Risso's dolphin Grampus griseus, Atlantic white-sided dolphin Lagenorhynchus acutus, humpback whale Megaptera novaeangliae, common eider Somateria mollissima, common loon Gavia immer, great black-backed gull Larus marinus, great cormorant Phalacrocorax carbo, greater shearwater Puffinus gravis, herring gull Larus argentatus and northern gannet Moras bassanus. The highest prevalence was in stranded seals $(58 \%)$, with the highest 


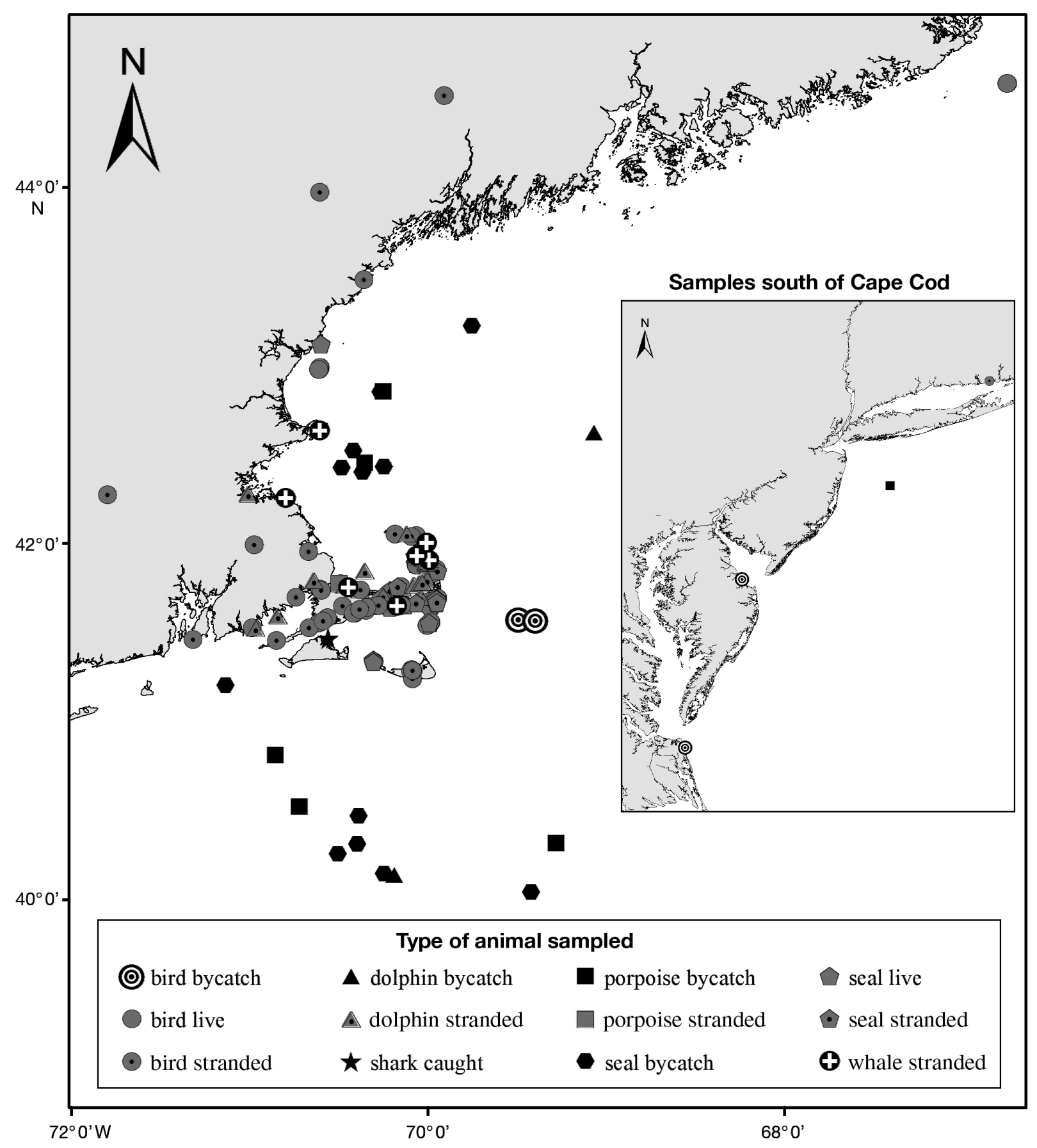

Fig. 1. Locations and types of bird and mammal samples examined for molecular analysis, microbiology and pathology

number of positive results in stranded birds (14). Brucella amplification products were detected in tissues including brain, liver, kidney, spleen, lung, testes, and tracheo-bronchial lymph node. Brucella spp. appeared to occur more commonly in males (Table 3) and more prevalent in samples collected from winter months (Table 4). Amplicon sequencing confirmed that the correct target was detected, and speciation of Brucella types is ongoing and will be reported elsewhere.

Brucella amplicons at times corresponded to pathologies that could be associated with infection. In a mass stranding of 9 common dolphins, 3 out of 5 dolphins sampled tested positive for Brucella spp. in the brain and uterus. Two dolphins were diagnosed with cervicovaginolithiasis, one associated with chronic endometri- 
Table 2. Prevalence (percentage positive) of target pathogens by PCR testing. N = number of individuals sampled. For Brucella, Leptospira and Cryptosporidium, parenthetical values are no. of individuals positive (all individuals tested); for Giardia, fraction indicates no. positive out of the no. of individuals in the tested subset

\begin{tabular}{|lcccccc|}
\hline Type & Animal & $\mathrm{N}$ & Brucella spp. & Leptospira spp. & Cryptosporidium spp. & Giardia spp. \\
\hline Live & Bird & 84 & & & $2(2)$ & $16(5 / 31)$ \\
& Seal & 95 & & & $23(22)$ & $10(4 / 40)$ \\
Stranded & Bird & 34 & $41(14)$ & $18(6)$ & 0 & $12(3 / 25)$ \\
& Seal & 12 & $58(7)$ & 0 & $25(3)$ & $16(1 / 6)$ \\
& Dolphin & 19 & $42(8)$ & 0 & 0 & $9(1 / 11)$ \\
& Porpoise & 1 & $29(2)$ & $28(2)$ & 0 & $100(1 / 1)$ \\
By-caught & Whale & 7 & $25(1)$ & $25(1)$ & 0 & $20(1 / 5)$ \\
& Bird & 4 & 0 & 0 & 0 & 0 \\
& Fish & 10 & $38(5)$ & $8(1)$ & 0 & $100(1 / 1)$ \\
& Seal & 13 & $50(1)$ & 0 & $14(1)$ & $25(1 / 4)$ \\
& Dolphin & 2 & 0 & $14)$ & $100(2 / 2)$ \\
& Porpoise & 7 & & 0 & 0 & $40(2 / 5)$ \\
\hline
\end{tabular}

tis with ecchymotic hemorrhaging in the right and left uterine horns. The third dolphin exhibited mild meningio-encephalitis with evidence of renal dysfunction. Additionally, a young stranded harp seal in which multiple tissues resulted in positive Brucella amplification, exhibited a vaginal myxoid leomyoma. Infections due to Brucella spp. in birds were not identified. Brucella cultures from samples sent to USDA were all negative.

Tissues from a total of 109 animals were analyzed for Leptospira spp. Positive amplification resulted in 11 animals from 9 species including stranded common eiders, common dolphin, unidentified dolphin species, humpback whale, harp seal, herring gull, northern gannet, one by-caught greater shearwater and one by-caught harp seal. Tissues that yielded amplicons included brain, kidney, liver, spleen, testes, tracheobronchial lymph, urine, feces and gut content. Leptospira PCR was negative for all samples analyzed by OADDL, and our sequencing of amplicons indicated that the correct target was not being recovered using the Lep1/Lep2 primer set, despite the correct size of the products.

A total of 236 animals were sampled for Cryptosporidium spp.: the parasite was detected in 30 animals including live seals, stranded seals, by-caught seals, live herring gulls and by-caught porpoise (Table 2).

Table 3. Seasonal distribution of pathogen detection (percentage positive) by PCR testing. Fall: Oct-Dec; Winter: Jan-Mar; Spring: Apr-Jun; Summer: Jul-Sep. Parenthetical values are no. of positive results out of no. of samples tested

\begin{tabular}{|lcccrrrrr|}
\hline Pathogen & \multicolumn{2}{c}{ Fall } & \multicolumn{2}{c}{ Winter } & \multicolumn{2}{c|}{ Spring } & \multicolumn{2}{c|}{ Summer } \\
\hline Leptospira spp. & 13.33 & $(2 / 15)$ & 18.18 & $(4 / 22)$ & 8.33 & $(2 / 24)$ & 10.00 & $(3 / 30)$ \\
Brucella spp. & 37.50 & $(6 / 16)$ & $60.87(14 / 23)$ & 27.27 & $(6 / 22)$ & 38.71 & $(12 / 31)$ \\
Giardia spp. & 30.77 & $(4 / 13)$ & $16.95(10 / 59)$ & 18.18 & $(6 / 33)$ & 4.76 & $(1 / 21)$ \\
Cryptosporidium & 17.78 & $(8 / 45)$ & 10.20 & $(5 / 49)$ & 6.15 & $(4 / 65)$ & 8.33 & $(4 / 48)$ \\
spp. & & & & & & & & \\
\hline
\end{tabular}

Table 4. Prevalence (percentage positive) of pathogen detection according to sex, based on the number of individuals of each sex tested (ND = sex could not be determined).

Parenthetical values indicate no. of individuals positive

\begin{tabular}{|lccc|}
\hline Pathogen & Female & Male & ND \\
\hline Brucella spp. & $24(9)$ & $74(28)$ & $3(1)$ \\
Leptospira spp. & $18(2)$ & $73(8)$ & $9(1)$ \\
Giardia spp. & $60(6)$ & $22(6)$ & $8.5(8)$ \\
Cryptosporidium spp. & $9(2)$ & $18(4)$ & $72(16)$ \\
Influenza A \& B & $0(0)$ & $3(1)$ & $3(1)$ \\
\hline
\end{tabular}

Samples obtained in fall months resulted in more positive results (Table 4). The highest prevalence was found in live seals (23\%) and stranded seals (25\%), specifically stranded harp seals Phoca groenlandica, live grey seals Halichoerus grypus, and samples collected from mixed haul-out sites of grey and harbor seals. Live herring gulls Larus argentatus $(\mathrm{n}=2)$ were the only bird species to test positive. Amplicon sequencing confirmed the correct target detection.

Giardia spp. amplifications are reported for only a portion of the sample set: 131 animals were tested, with a total of 22 positive for the parasite. Positives were found in animals of all species, with roughly equal prevalence for groups with sample numbers greater than 5 (Table 2). Animals included caught thresher shark Aliopias vulpinus, by-caught harbor seal Phoca vitulina, stranded and bycaught common dolphin Delphinus delphis, harbor porpoise Phocoena phocoena and Atlantic white-sided dolphin Lagenorhynchus acutus, stranded long-finned pilot whale Globicephala melas, Risso's dolphin Grampus griseus, harp seal Phoca 
groenlandica, and common eider Somateria mollissima. Live animals testing positive included herring gulls Larus argentatus, harbor seals $P$. vitulina and grey seals Halichoerus grypus. Again, a higher number of positive samples overall were recovered in fall and winter months (Table 3). Of 22 positives, 20 yielded amplification products and sequences for $G$. intestinalis speciation (Lasek-Nesselquist et al. 2008), but 2 yielded giardin products that shared sequence similarity with Assemblage F. Both of these samples were from live mixed grey/harbor seal populations.

Results have only been reported for samples for which the presence of Giardia has been confirmed elsewere by sequence analysis of the giardin product or via speciation of $G$. intestinalis (Lasek-Nesselquist et al. 2008). Amplification of fecal or gut sample extracts using the GGL/GGR primer set yielded several incorrect amplicons. One was a distinctly smaller band, which yielded a non-giardin sequence. The other was a band that appeared to be the correct size, but also yielded a non-giardin sequence.

\section{Bacterial culture and antibiotic resistance}

A total of 95 bacterial and 1 fungal species were identified to genus level at a minimum. Fecal and cloacal swabs, specifically those from live birds, had the greatest diversity of microbes cultured from routine and non-routine sites (Appendices $1 \& 2$ ). Non-routine sites include those related to pathology and infection sites including lesions, abscesses, urine, organs, and abdominal or thoracic fluid. Oral swabs were not taken in all animals and are considered non-pathology related for this survey. Aerobic Gram-negative bacilli comprised $76 \%$ of the isolates and $8.5 \%$ represented anaerobic organisms. Escherichia coli was most commonly isolated overall (152 isolates), especially in live and stranded birds and marine mammals. Pseudomonas spp., Clostridium perfringens, Enterobacter cloacae, Enterobacter spp., and Shewanella spp. were the next most commonly isolated. A total of 10 bacteria were only associated with non-routine culture sites. Of these, 9 were aerobic Gram-negative bacilli: Chromobacterium violaceum (kidney), Empedobacter brevis (kidney), Enterobacter sakazakii (uterus), Kluyvera spp. (genital), Providencia stuartii (omentum), Pseudomonas oryzihabitans (urine, spleen), Salmonella spp. (spleen), Sphingomonas spp. (spleen) and Vibrio fluvialis (genital). Brevibacterium spp. (mandible, periaortic) was the only anaerobic Gram-positive bacillus represented in non-routine culture swabs.

Appendix 3 lists bacteria isolated in this study that are recognized as human pathogens by the American Biological Safety Association (ABSA: www.absa.org/
XriskgroupsX/index.html), or other publications, along with references to published human infections where applicable. Sixty-eight of the bacterial isolates were recognized as human pathogens by ABSA $(71.6 \%)$, and a greater portion were identified by searching the medical literature for cases of human infection (up to $80 \%$ ). Many isolates appeared to be species-specific. Pasteurella multocida and Shewanella algae were only recovered from common eiders stranded in Wellfleet, Massachusetts. Enterococcus faecalis was only recovered from stranded birds. Isolates of Ewingella americana and Peptostreptococcus spp. were only recovered from cetaceans. Chryseobacterium indologenes was only recovered from by-caught seals, while Clostridium spp. were most common in samples from live seals.

Antibiotic resistance (ABR) for each isolate ranged from 0 to 13 antibiotics. Of bacterial isolates, $61 \%$ were resistant to at least one antibiotic, while $58.8 \%$ were resistant to more than one. Isolates with a MAR value of 1 (i.e. resistant to all antibiotics tested) were a Serratia marcesens and a Shewanella spp. from a stranded hooded seal, but these isolates were tested with a limited number of antibiotics (6 and 3 respectively), so it is unknown whether this value would have remained high if the others were tested. $38.7 \%$ of our isolates had a 0 MAR value, $30.9 \%$ had a MAR value $>0$ but $<0.2$, while $30.0 \%$ had a MAR value $>0.2$. The bacterial isolate that was resistant to the greatest number of antibiotics was a Chryseobacterium indologenes from a by-caught harp-seal that showed resistance to 13 out of 16 antibiotics. The animal yielding the greatest percentage of isolates with multiple resistances was a stranded meningioencepahlitic Cuvier's beaked whale, where 7 of the 8 isolates tested for $\mathrm{ABR}$ were resistant to $>4$ antibiotics. Antibiotics to which isolates showed the least resistance were ciprofloxacin (2\%), enrofloxacin $(2 \%)$, gentamicin $(4 \%)$, oxacillin, vancomycin, and erythromycin. The antibiotics with the highest number of resistant isolates included cephalothin (39\%), ampicillin (34\%), augmentin (26\%) and carbenicillin $(26 \%)$.

\section{Influenza}

Influenza A and B were tested in 34 samples. There were 2 positive samples for influenza A but none for influenza B. Influenza A, avian influenza H3N8 virus, was detected in one by-caught harp seal. Influenza A, negative for $\mathrm{H} 5$ or $\mathrm{H} 7$, was detected in one live herring gull from Kent Island, Canada. The avian influenza type isolated was confirmed not to be of agricultural interest but the actual type has yet to be confirmed. 
Table 5. Most significant findings based on necropsy and histopathology findings

\begin{tabular}{|lc|}
\hline Finding & No. of cases (\%) \\
\hline Infectious disease & $37(26)$ \\
Mass stranding - no significant findings & $28(19)$ \\
Other & $15(10)$ \\
Tournament/hunt & $13(9)$ \\
Parasites & $12(8)$ \\
Bycatch-no significant findings & $8(6)$ \\
Bycatch-bubbles & $9(6)$ \\
Could not be determined & $7(5)$ \\
Bycatch-disease & $6(4)$ \\
Human interaction & $5(3)$ \\
Emaciation & $2(1)$ \\
Bycatch-other & $2(1)$ \\
Predation & $1(1)$ \\
Total individuals & $145(100)$ \\
\hline
\end{tabular}

\section{Significant findings in mortality cases}

A diagnosis based on significant findings or ultimate cause of death based on history, gross and histopathology results was assigned to 115/121 (96\%) of animals (Table 5). Six cases could not be diagnosed based on available data. The most common significant findings were related to infectious disease $(31 \%)$ followed by the category of other $(12 \%)$ which includes trauma involving wing fracture, con-specific aggression, a wound of unknown origin or moving vehicle, obvious gross changes such as peritonitis with no apparent cause, gastrointestinal obstruction, congenital defect, and dependent pup or calf not able to forage independently. Parasites as the primary cause of stranding and mortality were highest in common eiders $(10 \%$ of the cases). Of animals that were fishery by-caught, the majority had no significant findings $(7 \%)$ other than pathology associated with drowning and/or were found by gross and histopathology to exhibit gas emboli $(7 \%)$ in lymph nodes, brain, myocardium, adrenal glands, spleen, skeletal muscle, and kidney.

In general, the pathologies were variable, but some were observed more often in particular circumstances. For example, the pathologies most often seen in stranded animals included peritonitis, septicemia, hepatitis, aspergillosis, enterotoxemia, reduced nutritional state, bacterial and verminous enteritis, verminous gastritis, and interstitial and bronchopneumonia. A summary of pathologies noted in relation to bacteria isolated can be found in Appendix 3.

\section{DISCUSSION}

Marine mammals, sea birds and sharks of the NW Atlantic harbor zoonotic bacteria including Brucella spp. and Leptospira spp., protozoan pathogens Cryp- tosporidium spp. and Giardia spp., and multiple strains of zoonotic bacteria that are resistant to multiple antibiotics used in both human and animal treatment. One marine mammal and one sea bird also tested positive for avian influenza, specifically H3N8 in a bycaught harp seal and unspecified non H5 type in a herring gull.

Brucella spp. was the most commonly detected target zoonosis found in both stranded marine mammals and sea birds. Isolation and detection of Brucella spp. has been documented in harbor and harp seals along the coast of southern New England (Connecticut and Rhode Island) with no gross or histological changes associated with infection (Maratea et al. 2003). Six species of Brucella are currently recognized and ongoing research suggests 3 additional specific to marine mammals: B. pinnipedialis and B. ceti (Foster et al. 2002, 2007 ) or B. phocae and B. phocoenoae and B. delphini (Groussaud et al. 2007). Marine mammal Brucella strains have been isolated in association with pathology and infection in humans, although these cases did not involve direct contact with infected marine mammals: one was a laboratory technician who was infected in a laboratory (Brew et al. 1999), and the others were 2 individuals from Peru who had no contact with marine mammals (Sohn et al. 2003). In marine mammals, infection is characterized by chronic infection which can lead to weight loss, inflammation, abortion and infertility (Koneman et al. 1988, Miller et al. 1999), menigioencephalitis (Gonzalez et al. 2002) and bone disease (Dagleish et al. 2007).

With regards to the cervicovaginolithiasis described in common dolphins, over the course of $8 \mathrm{yr}$ of marine mammal stranding reports by the Cape Cod Stranding Network, this was the first recorded instance of vaginal stones in cetaceans. Presence of vaginal calculi in stranded dolphins has been hypothesized to be composed of calcium phosphate and the result of ossification of a developing or aborted fetus (Sawyer \& Walker 1977, Benirschke et al. 1984, Woodhouse \& Rennie 1991). Immunohistochemistry and sequencing of these amplicons are underway and will be reported elsewhere.

In terms of Brucella amplicons in birds, previously published studies note positive antibody response to Brucella abortus and Brucella melitensis in domestic fowl without isolation and identification of the organism (Abdu et al. 1984, Kumar et al. 1984, Kudi et al. 1997, Junaidu et al. 2006). The presence of the bacterial amplicon in birds, and at the high frequency seen in this study, suggests wild birds could be a source of infection for other species.

Leptospirosis is considered the most widespread zoonosis in the world (Levett 2001). While the west coast of the USA has experienced severe epizootics of 
Leptospira interrogans in pinnipeds, populations on the east coast appeared to remain naïve (Gulland et al. 1996, Stamper et al. 1998, Colegrove et al. 2005), although leptospirosis is known to be enzootic in western and central Massachusetts (Andrew \& Marrocco 1977). Samples in our study that yielded amplification products included a harp seal, a humpback whale, unidentified species of dolphin, common dolphin, common eider, great cormorant, greater shearwater, herring gull and northern gannet. As pathologies corresponding to leptospirosis were not noted in these animals, the diversity of hosts could represent nonpathogenic species from the marine environment. Sequencing of amplicons from the humpback gut content sample and an eider bursa sample indicated that approximately $300 \mathrm{bp}$ products were similar to Atopobium spp. (87 and $95 \%$ respectively), members of the Coriobacteriacea (Actinobacteria). These results indicate that the primer set was not amplifying the correct product in our samples, and that the positive results we obtained were not indicative of Leptospira. We have chosen to report these results in order to document the problem, and we intend to re-analyze the samples using a different set of Leptospira primers (Cameron et al. 2008).

Giarda and Cryptospordium are intestinal protozoan parasites (Fayer 2004, Ford 2005) that infect a wide range of animals, including humans. The presence of Giardia spp. and Cryptosporidium spp. in marine mammals indicates that these animals can serve as vectors of these primarily fresh-water parasites, and could be acquiring them from anthropogenic sources. There is also the possibility that novel marine strains of these parasites exist, and this is supported by the discovery of novel seal genotypes of Cryptosporidium (Santin et al. 2005). Giardia found in samples from marine mammals, sea birds and a shark (this study) have been confirmed as $G$. intestinalis of human Assemblages A and B (Lasek-Nesselquist et al. 2008) and members of the Assemblage $F$ were also present in seals. To our knowledge, our study is the first to report on the prevalence of Giardia in wild dolphins and porpoises. Other studies have reported on the prevalence of Giardia in seals and whales, although genotyping has not routinely been accomplished (Olson et al. 1997, 2004, Measures \& Olson 1999, Hughes-Hanks et al. 2005). Ringed, grey, harp and harbor seals, as well as right and bowhead whales have all been found to harbor Giardia spp. with a general prevalence between 20 and $30 \%$, with 2 exceptions (Hughes-Hanks et al. 2005) of much higher prevalences for ringed seals $(64.5 \%)$ and right whales $(71.4 \%)$. This study showed similar, and in some cases lower, prevalence values (Table 2). There was also some variability in prevalence, and this may be due to the small sample sizes and the general health of the animal (live, stranded or by-caught). When the prevalence of Giardia was calculated without considering animal status, the values became $12 \%$ for seals, $13 \%$ for birds, $23 \%$ for dolphins, $20 \%$ for whales and $50 \%$ for porpoises.

Our results for Cryptosporidium are in distinct contrast to our findings for Giardia. Cryptosporidium was found only in seals and porpoises, and in a very small number of our birds. The prevalence values for seals and porpoises are close to those observed in other marine mammal studies (18 to $24 \%$ ) (Hill et al. 1997, Deng et al. 2000, Hughes-Hanks et al. 2005, Santin et al. 2005). Sequence analysis of our amplification fragments from seals indicated that they were not harboring C. parvum, but appeared to carry species related to $C$. muris and a Type 2 novel seal isolate (Santin et al. 2005).

Tables 3 \& 4 illustrate some of the general trends we observed in our data. In Table 3, we examined the potential for season to influence the detection of the pathogens. Animals collected in fall and winter had higher prevalences of Giardia, Cryptosporidium and Brucella, and this raises questions about how temperature and other seasonal parameters (freshwater input, migration, mating, food resources) impact pathogen prevalence. We also examined the detection of pathogens by sex (Table 4); of particular interest is the preponderance of Brucella in males, which raises the question of whether the association of Brucella and abortion has lead to a misplaced focus on females. The increased prevalence of Giardia in females is also interesting, and suggests there may be behavioral factors involved in the presence of this particular pathogen.

The majority of bacteria isolated in our study were recognized as human pathogens or potential human pathogens. All pathogens found in common between marine mammals, sea birds and sharks are recognized by the ABSA as human pathogens: Acinetobacter calcoaceticus-baumannii, Citrobacter braaki, C. freundii, Enterobacter cloacae, Leclercia adecarboxylata, Morganella morganii, Pseudomonas aeruginosa, Pseudomonas spp., Shewanella spp. and Stenotrophomonas maltophilia. Other isolates recovered that are known to cause infection in humans from handling fish include Aeromonas hydrophila, Edwardsiella tarda, Vibrio cholera, and V. parahaemolyticus (Harper 2002). The routine microbiological survey did report non-pathogenic organisms when present, but did not assess antibiotic resistance.

The recovery of antibiotic resistant bacterial isolates from marine animals was not unexpected. Other studies have reported the presence of antibiotic resistant bacteria in marine animals (Johnson et al. 1998, Smith et al. 2002, Foster et al. 2004, Stoddard et al. 2005, Buck et al. 2006) and bacteria isolated from marine 
birds at rehabilitation facilities in California also frequently yielded Escherichia coli (Steele et al. 2005), with over $50 \%$ of isolates resistant to ampicillin. Our study is the first to examine such a wide range of organisms and sample types (tissues as well as external swabs). One of the most interesting findings in this study was the presence of multiple antibiotic resistant bacteria in a Cuvier's beaked whale, a species associated with deep water (1000 to $3700 \mathrm{~m}$ ) and rarely seen in coastal environments (Ferguson et al. 2006). Isolates included: Photobacterium damiela resistant to augmentin, ampicillin, carbenicillin, cephalothin, and ticarcillin; several Pseudomonas spp. resistant to augmentin, ampicillin, carbenicillin, ceftazime, cephalothin, and chloramphenicol; and Acinetobacter calcoaceticus-baumannii resistant to ampicillin, ceftazime, cephalothin, and chloramphenicol. Clostridium perfringens, Candida glabbata, Pseudomonas oryzihabitans, and Staphlococcus spp. were also isolated from this animal. Where this animal acquired bacteria with levels of antibiotic resistance indicative of significant contamination is a question that remains unanswered, and merits further study. However, given the finding of significant PCB burdens in deep sea fish (Stegeman et al. 1986), it would seem that terrestrial sources of these drug resistance genes may similarly have deep water sinks. It is also interesting that high ambient pressure may in itself enhance antibiotic resistance development (Hind \& Attwell 1996).

Thresher and mako sharks sampled off Martha's Vineyard, Massachusetts in this study also exhibited bacterial isolates with multiple antibiotic resistances. The isolates averaged resistance to 4 antibiotics, with a range of 0 to 8 , augmentin and cephalothin resistance being the most common. Although our sample set was small, the resistance in sharks corroborates previous findings of antibiotic resistant bacteria in smooth dogfish shark Mustelus canis from the same area and a study of nurse Ginglymostoma cirratum, bull Carcharhinus leucas and spinner sharks Carcharhinus brevipinna (Blackburn 2003). Some of these sharks do forage in coastal environments, and even those that do not may encounter food that has come from the coastal environment. Our lack of knowledge regarding the natural histories of many of these animals limits our ability to identify sources of contamination.

The overall prevalence of isolates resistant to multiple antibiotics, and the number of isolates that had MAR indices $>0.2(30.9 \%)$ were surprising. MAR values $>0.25$ are considered to represent exposure to point-source contamination (usually human fecal) (Kruperman 1983, Kaspar et al. 1990, Parveen et al. 1997). In our results $27.4 \%$ of our isolates had a MAR value $>0.25$, suggesting that the animals were being exposed to significant contamination. It seems reasonable to consider where and/or how these animals are being exposed, not only with concern for their health, but the fact that they can serve as vectors of antibiotic resistant bacteria over ranges that can exceed $10^{\circ}$ of latitude/longitude.

The presence of multiple antibiotic resistance in isolates that are not recognized as pathogens is also extremely important, as this indicates that commensal or environmental bacteria can serve as reservoirs for resistance genes. While it is generally agreed that the widespread use of antibiotics has resulted in significant increases in antibiotic resistance, recent work has shown that even after the removal of the selective pressure of individual or groups of antibiotics, resistance levels have been slow to decline (Heuer et al. 2002, Sørum et al. 2006). This suggests that the maintenance of resistance genes is not necessarily detrimental to cells, and that there may be other factors associated with the maintenance of these genes (e.g. heavy metals) (Sjogren \& Port 1981, Baker-Austin et al. 2006). The overall concern is that commensal and environmental bacteria are not only able to acquire and maintain resistance genes, but that they are able to multiply and spread them to others, including back to pathogenic species either in the environment or in the host. Most of the marine animals sampled have extensive migratory and foraging ranges, and it is likely that they could serve as vectors in the spread of antibiotic resistance in the marine environment.

Our results indicate that marine mammals, fish and seabirds may not only suffer as victims of disease from zoonotic pathogens, but also act as vectors, moving these human bacterial and protozoal pathogens to different geographic locations in the ocean and terrestrial environments. Marine animals interact with each other as predators, scavengers and through the shared use of marine and beach environments. Documentation of seals predating on sea birds, sea birds predating and scavenging on marine mammals and sharks predating on marine mammals out of rehabilitation facilities are a few examples that support this hypothesis (Tallman \& Sullivan 2004). They come into contact with humans and terrestrial animals as food resources, during stranding events and through shared use of beach environments. The prevalence of human genotypes of Giardia intestinalis in both seals and gulls that share local beach environments is intriguing, and whether this represents contamination of the marine populations from human sources remains a question. While our knowledge regarding the presence of zoonotic agents in marine animals is progressing rapidly, very little is known about the potential impacts of these agents on both marine animal health and potential risks to human health. 
The long-distance migration of marine vertebrates and their specific ocean usage areas of the marine environment may allow for specific patterns in anthropogenic movement of infected host pathogen pollution (Daszak et al. 2001). In combination with global climate change, fishery decline, poor nutritional status, and overlap of new populations, pathogen exchange in these areas can occur. For instance, it is widely believed that harp seals foraged further south in 1987 when fish populations decreased in the Barents Sea, which in turn allowed harp seals carrying phocine distemper virus (PDV) to interact with naïve populations, initiating the 1988 PDV outbreak in harbor seals (Dietz et al. 1989, Heide-Jørgensen et al. 1992, Gulland \& Hall 2003, Härkönen et al. 2006). Leptospira outbreaks, and the presence of Toxoplasma gondii in sea otters in California are also examples of increasing human populations, interactions with wildlife and disease transmission (Stamper et al. 1998, Miller et al. 2002). Transmission from humans to marine life is evident in the unique case of influenza B transmission to a seal (Osterhaus et al. 2000). This evidence reminds us that while wildlife may act as vectors of zoonotic disease, their role as sentinels to the abundance and distribution of human waste is one that needs more attention. It is important to establish what may be endemic to marine environments (e.g. Vibrio spp. carrying antibiotic resistance) versus what is introduced by anthropogenic activity. Ongoing studies are using microbial source tracking methods to determine whether seabirds (gulls in particular) harbor fecal pathogens derived from anthropogenic sources, and if these pathogens are transmitted via birds to other coastal animals such as seals.

The overall goal of this research was to assess prevalence of subclinical and clinical zoonoses in marine mammal and birds of the Northwest Atlantic and bring awareness of the diversity of emerging and potential pathogens. This region supports some of the largest fisheries in the world, is recognized as an important breeding and nesting region for coastal birds, supports a large diversity of marine mammals and is an area where coastal human communities are becoming increasingly overcrowded. Concern regarding wildlife and human interactions raise the need to understand what pathogens are able to infect both, and which ones may be increasing in occurrence due to anthropogenic activities. More importantly, wide distribution of information between researchers and users of the ocean environment will help determine where pathogens originate, where they might be going and how best to prevent exposure. In this regard it is significant that a recent review of emerging infectious diseases shows the northeast of the USA as having the highest relative risk for emerging infectious diseases in the country (Jones et al. 2008).
Acknowledgements. This paper is a result of research funded by the National Oceanic and Atmospheric Administration (NOAA) Coastal Ocean Program under award NA05NOS4781247, the NOAA John H. Prescott Program NA05NMF4391165 and NAO6NMF4390130, and the International Fund for Animal Welfare to the Woods Hole Oceanographic Institution. Support was also provided by awards NSF OCE-0430724 and NIEHS P50ES012742 to the Woods Hole Center for Ocean and Human Health. Research was conducted in compliance with a US Fish and Wildlife Service special purpose salvage permit, Massachusetts state permit to salvage027.04SAL, IUCAC-\# MB804639-0, IUCAC-\# G87207 and NMFS Permit No. 775-1600-10. The authors are grateful to NOAA NEFSC Protected Species and Observer Program, B. Hayward, and the many observers and captains for collection of fishery by-caught animals; R. Cook, National Park Service; Cape Cod Commercial Hook Fishermen's Association; B. Harris, Massachusetts Audubon Coastal Bird Program; Massachusetts Audubon, Wellfleet; L. Dunn, R. Rolland, G. Skomal, K. Ampela, C. Blachly, D. Rotstein, M. Garner and H. Ip; R. Mauck and N. Wheelwright, Kent Island field station (Bowdoin College); and Shoals Marine Laboratory. The authors are also grateful to S. Frasca, I. Sidor and the Bay Paul Center for Comparative Molecular Biology and Evolution at the Marine Biological Laboratory (MBL) for providing genomic DNA from Leptospira, Brucella, and Giardia.

\section{LITERATURE CITED}

Abdu P, Edesiyun A, Abdullahi S (1984) Serological evidence of brucellosis, Q fever, salmonellosis and mycoplasmosis in chickens from nomadic herds around Zaria. Niger Vet J 13:61-62

Acevedo-Whitehouse K, de la Cueva H, Gulland FMD, Aurioles-Gamboa D, Arellano-Carbajal F, Suarez-Gueemes F (2003) Evidence of Leptospira interrogans infection in California sea lion pups from the Gulf of California. J Wildl Dis 39:145-151

Andrew ED, Marrocco GR (1977) Leptospirosis in New England. JAMA 238:2027-2028

Baily GG, Krahn JB, Drasar BS, Stoker NG (1992) Detection of Brucella melitensis and Brucella abortus by DNA amplification. J Trop Med Hyg 95:271-275

Baker-Austin C, Wright M, Stephanauskas R, McArthur JV (2006) Co-selection of antibiotic and metal resistance. Trends Microbiol 14(4):176-182

Benirschke K, Henderson JR, Sweeny JC (1984) A vaginal mass containing fetal bones, in a common dolphin (Delphinus delphis). In: Perrin W, Brownell R, DeMaster D (eds) Reports of the International Whaling Commision, Special Issue 6. IWC, Cambridge, p 457-458

Bernard KA, Maffei JG, Jones SA, Kauffman EB and others (2001) West Nile virus infection in birds and mosquitos, New York State, 2000. Emerg Infect Dis 7:679-685

Bizet J, Bizet C (1997) Strains of Alcaligenes faecalis from clinical material. J Infect 35:167-169

Blackburn JK (2003) Characterizing spatially explicit patterns of antibiotic resistance in the marine environment using top-level predators. Masters thesis, Louisiana State University, Shreveport, LA

Boinapally K, Jiang X (2007) Comparing antibiotic resistance in commensal and pathogenic bacteria isolated from wildcaught South Carolina shrimps vs. farm-raised imported shrimps. Can J Microbiol 53:919-924

Brew S, Perrett L, Stack J, MacMillan A, Staunton N (1999) Human exposure to Brucella recovered from a sea mam- 
mal. Vet Rec 144:483

Buck JD, Wells RS, Rhinehart HL, Hansen LJ (2006) Aerobic microorganisms associated with free-ranging bottlenose dolphins in coastal Gulf of Mexico and Atlantic Ocean waters. J Wildl Dis 42:536-544

Callan RJ, Early G, Kida H, Hinshaw VS (1995) The appearance of H3 influenza viruses in seals. J Gen Virol 76:199-203

> Cameron CE, Zuerner RL, Raverty S, Colegrove KM and others (2008) Detection of pathogenic Leptospira bacteria in pinniped populations via PCR and identification of a source of transmission of zoonotic leptospirosis in the marine environment. J Clin Microbiol 46:1728-1733

Clark GM, O'Meara D, Weelden JWV (1958) An epizootic among eider ducks involving an acanthocephalid worm. J Wildl Manag 22:204-205

Colegrove KM, Lowenstine LJ, Gulland F (2005) Leptospirosis in Northern elephant seals (Mirounga angustirostris) stranded along the California coast. J Wildl Dis 41: $426-430$

Cruz A, Cazacu A, Allen C (2007) Pantoea agglomerans, a plant pathogen causing human disease. J Clin Microbiol 45:1989-1992

Dagleish MP, Barley J, Howie FE, Reid RJ, Herman J, Foster G (2007) Isolation of Brucella species from a diseased atlanto-occipital joint of an Atlantic white-sided dolphin (Lagenorhynchus acutus). Vet Rec 160:876-877

Daszak P, Cunningham AA, Hyatt AD (2001) Anthropogenic environmental change and the emergence of infectious diseases in wildlife. Acta Trop 78:103-116

Deng MQ, Peterson RP, Cliver DO (2000) First findings of Cryptosporidium and Giardia in California sea lions (Zalophus californianus). J Parasitol 86:490-494

Dietz R, Heide-Jørgensen MP, Härkönen T (1989) Mass deaths of harbor seals (Phoca vitulina) in Europe. Ambio 18(5):258-264

Dobson AP, Carper E (1996) Infectious disease and human population history. BioScience 46:115-126

Duignan PJ, House C, Geraci JR, Duffy N and others (1995) Morbillivirus infection in cetaceans of the western Atlantic. Vet Microbiol 44:241-249

Fayer R (2004) Cryptosporidium: a water-borne zoonotic parasite. Vet Parasitol 126(1-2):37-56

Ferguson M, Barlow J, Rilly S, Gerrodette T (2006) Predicting Cuvier's (Ziphius cavirostris) and Mesoplodon beaked whale population density from habitat characteristics in the Eastern Tropical Pacific Ocean. J Cetacean Res Manag 7:287-299

Ford B (2005) The discovery of Giardia. Microscope 53: $147-153$

Foster G, MacMillan AP, Godfroid J, Howie F and others (2002) A review of Brucella sp. infection of sea mammals with particular emphasis on isolates from Scotland. Vet Microbiol 90(1-4):563-580

Foster G, Holmes B, Steigerwalt AG, Lawson PA and others (2004) Campylobacter insulaenigrae sp. nov., isolated from marine mammals. Int J Syst Evol Microbiol 54: 2369-2373

Foster G, Osterman B, Godfroid J, Jacques I, Cloeckaert A (2007) Brucella ceti sp. nov. and Brucella pinnipedialis sp. nov. for Brucella strains with cetaceans and seals as their preferred hosts. Int J Syst Evol Microbiol 57:2688-2693

Geraci JR, St. Aubin DJ, Barker IK, Webster RG and others (1982) Mass mortality of harbor seals: pneumonia associated with influenza A virus. Science 215:1129-1131

Geraci JR, Anderson DM, Timperi RJ, St. Aubin DJ, Early GA, Prescott JH, Mayo CA (1989) Humpback whales (Megaptera novaeangliae) fatally poisoned by dinoflagellate toxin. Can J Fish Aquat Sci 46:1895-1898
Goetz A, Yu VL, Hanchett JE, Rihs JD (1983) Pseudomonas stutzeri bacteremia associated with hemodialysis. Arch Intern Med 143:1909-1912

Gonzalez L, Patterson IA, Reid RJ, Foster G and others (2002) Chronic meningoencephalitis associated with Brucella sp. infection in live-stranded striped dolphins (Stenella coeruleoalba). J Comp Pathol 126:147-152

Graczyk TK, Balazs GH, Work T, Aguirre AA, Ellis DM, Murakawa SKK, Morris R (1997) Cryptosporidium sp. infections in green turtles, Chelonia mydas, as a potential source of marine waterborne oocysts in the Hawaiian Islands. Appl Environ Microbiol 63:2925-2927

Grohskopf LA, Roth VR, Feikin DR, Arduino MJ and others (2001) Serratia liquefaciens bloodstream infections from contamination of epoetin alfa at a hemodialysis center. N Engl J Med 344(20):491-497

Groussaud P, Shankster SJ, Koylass MS, Whatmore A (2007) Molecular typing divides marine mammal strains of Brucella into at least three groups with distinct host preferences. J Med Microbiol 56:1512-1518

Gulland F, Hall A (2003) The role of infectious disease in influencing status and trends. In: Reynolds J, Perrin W, Reeves R, Montgomery S, Ragen T (eds) Marine mammal research. Johns Hopkins University Press, Baltimore, MD

Gulland FMD, Koski M, Lowenstine LJ, Colagross A, Morgan L, Spraker T (1996) Leptospirosis in California sea lions (Zalophus californianus) stranded along the central California coast, 1981-1994. J Wildl Dis 32:572-580

Härkönen T, Dietz R, Reijnders P, Teilmann J and others (2006) The 1988 and 2002 phocine distemper virus epidemics in European harbour seals. Dis Aquat Org 68: $115-130$

Harper C (2002) Zoonotic diseases acquired from fish. Aquacult Mag 28:55-58

Harvell CD, Burkholder K, Colwell J, Epstein P and others (1999) Emerging marine diseases - climate links and anthropogenic factors. Science 285:1505-1510

Hauschild AHW, Gauvreau L (1985) Food-borne botulism in Canada, 1971-84. CMAJ 133:1141-1146

Heide-Jørgensen MP, Härkönen T, Dietz R, Thompson PM (1992) Retrospective of the 1988 European seal epizootic. Dis Aquat Org 13:37-62

Henkel JS, Armstrong D, Blevins A, Moody MD (1970) Group A beta hemolytic streptococcus bacteremia in a cancer hospital. JAMA 211(6):983-986

Heuer OE, Pedersen K, Jensen LB, Madsen M, Olsen JE (2002) Persistence of vancomycin-resistant enterococci (VRE) in broiler houses after the avoparcin ban. Microb Drug Resist 8:355-361

Hill B, Frazier IR, Prior HC (1997) Cryptosporidium infection in a dugong (Dugong dugon). Aust Vet J 75:640-641

Hind J, Attwell RW (1996) The effect of antibiotics on bacteria under hyperbaric conditions. J Antimicrob Chemother 37: 253-263

Hinshaw VS, Bean WJ, Webster RG, Rehg JE and others (1984) Are seals frequently infected with avian influenza viruses? J Virol 51:863-865

Horimoto T, Kawaoka Y (2001) Pandemic threat posed by avian influenza A viruses. Clin Microbiol Rev 14: 129-149

Hughes-Hanks JM, Rickard LG, Panuska C, Saucier JR, O'Hara TM, Dehn L, Rolland RM (2005) Prevalence of Cryptosporidium spp. and Giardia spp. in five marine mammal species. J Parasitol 91:1225-1228

Jankowsky J, Schuler K, Bradsby J (2007) USGS National Wildlife Health Center quarterly wildlife mortality report July 2007 to September 2007. USGS National Wildlife 
Health Center, Madison, WI. Available at: www.nwhc. usgs.gov/publications/quarterly_reports/2007_qtr_4.jsp

Johnson DC, Enriquez CE, Pepper IL, Davis TL, Gerba CP Rose JB (1997) Survival of Giardia, Cryptosporidium poliovirus and Salmonella in marine waters. Water Sci Technol 35:261-268

Johnson SP, Nolan S, Gulland FM (1998) Antimicrobial susceptibility of bacteria isolated from pinnipeds stranded in central and northern California. J Zoo Wildl Med 29 288-294

Jones KE, Patel N, Levy M, Storeygard A, Balk D, Gittleman J, Daszak P (2008) Global trends in emerging infectious diseases. Nature 451:990-994

Junaidu A, Salihu M, Ahmed F, Ambursa M, Gulumbe M (2006) Brucellosis in local chickens in north western Nigeria. Int J Poult Sci 5:547-549

Kaspar CW, Burgess JL, Knight IT, Colwell RR (1990) Antibiotic resistance indexing of Escherichia coli to identify sources of fecal contamination in water. Can J Microbiol 36:891-894

Kawula TH, Lelivelt MJ, Orndorff P (1996) Using a new inbred fish model and cultured fish tissue cells to study Aeromonas hydrophila and Yersinia ruckeri pathogenesis. Microb Pathog 20:119-125

Koneman EK, Allen SD, Dowell VR, Jandra WM, Sommer HM, Winn WC (1988) Color atlas and textbook of diagnostic microbiology, 3rd edn. J. B. Lippincott, Philadelphia, PA

Kruperman PH (1983) Multiple antibiotic resistance indexing of Escherichia coli to identify high-risk sources of fecal contamination of foods. Appl Environ Microbiol 46 165-170

Kudi AC, Kalla DJU, Kudi MC, Yusuf H (1997) Serological survey of brucellosis in traditionally managed domestic fowl in northern Guinea savannah, Nigeria. Worlds Poult Sci J 53:287-289

Kumar S, Kulshrestha RC, Bhatia KC, Kaushik RK (1984) Brucellosis in poultry-an experimental study. Int J Zoonoses 11:133-138

Lafferty KD, Porter J, Ford S (2004) Are diseases increasing in the ocean? Annu Rev Ecol Evol Syst 35:31-54

- Lasek-Nesselquist E, Bogomolni AL, Gast RJ, Welch DM, Ellis JC, Sogin ML, Moore MJ (2008) Molecular characterization of Giardia intestinalis haplotypes in marine animals: variation and zoonotic potential. Dis Aquat Org 81 39-51

- Levett PN (2001) Leptospirosis. Clin Microbiol Rev 14 296-326

> Mahbubani MH, Bej AK, Perlin MH, Schaefer FW III Jakubowski W, Atlas RM (1992) Differentiation of Giardia duodenalis from other Giardia spp. by using polymerase chain reaction and gene probes. J Clin Microbiol 30:74-78

Maratea J, Ewalt DR, Frasca S, Dunn JL and others (2003) Evidence of Brucella sp. infection in marine mammals stranded along the coast of southern New England. J Zoo Wildl Med 34:256-261

Mayer CL, Palmer CJ (1996) Evaluation of PCR, nested PCR and fluorescent antibodies for detection of Giardia and Cryptosporidium species in wastewater. Appl Environ Microbiol 62:2081-2085

McCallum H, Harvell D, Dobson A (2003) Rates of spread of marine pathogens. Ecol Lett 6:1062-1067

Measures LN, Olson M (1999) Giardiasis in pinnipeds from eastern Canada. J Wildl Dis 35:779-782

Merien F, Amouriaux P, Perolat P, Baranton G, Saint Girons (1992) Polymerase chain reaction for detection of Lep tospira spp. in clinical samples. J Clin Microbiol 30: 2219-2224

Miller MA, Gardner IA, Kreuder C, Paradies DM and others (2002) Coastal freshwater runoff is a risk factor for Toxoplasma gondii infection of southern sea otters (Enhydra lutris nereis). Int J Parasitol 32:997-1006

Miller WG, Adams LG, Ficht TA, Cheville NF and others (1999) Brucella induced abortions and infection in bottlenose dolphins (Tursiops truncatus). J Zoo Wildl Med 30:100-110

Moore C, Norton R (1995) Corynebacterium aquaticum septicaemia in a neutropenic patient. J Clin Pathol 48:971-972

Morse SS (1993) Examining the origins of emerging viruses. In: Morse SS (ed) Emerging viruses. Oxford University Press, New York, p 10-28

Myers G, MacInnes K, Myers L (1993) Phylogenetic moments in the AIDS epidemic. In: Morse SS (ed) Emerging viruses. Oxford University Press, New York, p 120-137

Olson ME, Roach PD, Stabler M, Chan W (1997) Giardiasis in ringed seals from the western Arctic. J Wildl Dis 33: 646-648

Olson M, Appelbee A, Measures L (2004) Giardia duodenalis and Cryptosporidium parvum infections in pinnipeds. Vet Pathol 125:131-132

Osterhaus ADME, Rimmelzwaan GF, Martina BEE, Bestebroer TM, Fouchier RAM (2000) Influenza B virus in seals Science 288:1051-1053

Parveen S, Murphree RL, Edmiston L, Kaspar CW, Portier KM, Tamplin ML (1997) Association of multiple-antibioticresistance profiles with point and nonpoint sources of Escherichia coli in Apalachicola Bay. Appl Environ Microbiol 63:2607-2612

Pounds JA, Bustamante MR, Coloma LA, Consuegra JA and others (2006) Widespread amphibian extinctions from epidemic disease driven by global warming. Nature 439: 161-167

Pugliares KR, Bogomolni A, Touhey KM, Herzig SM, Harry CT, Moore M (2007) Marine mammal necropsy: an introductory guide for stranding responders and field biologists. Woods Hole Oceanographic Institution, Woods Hole, MA

Quevedo S, Martin M, Velasco A (2006) Moellerella wisconsensis: a hidden enteric pathogen? Clin Microbiol Newsl 28(18):142-143

Rappole JH, Derrickson SR, Hubalek Z (2000) Migratory birds and spread of West Nile virus in the western hemisphere. Emerg Infect Dis 6:319-328

Rochelle PA, De Leon R, Stewart MH, Wolfe RL (1997) Comparison of primers and optimization of PCR conditions for detection of Cryptosporidium parvum and Giardia lamblia in water. Appl Environ Microbiol 63:106-114

Santin M, Dixon BR, Fayer R (2005) Genetic characterization of Cryptosporidium isolates from ringed seals (Phoca hispida) in Northern Quebec, Canada. J Parasitol 91:712-716

Sawyer J, Walker W (1977) Vaginal calculi in the dolphin. J Wildl Dis 13:346-348

Schmidt U, Chmel H, Cobbs C (1979) Vibrio alginolyticus infections in humans. J Clin Microbiol 38(3):1258-1262

Sjogren RE, Port J (1981) Heavy metal-antibiotic resistant bacteria in a lake recreational area. Water Air Soil Pollut 15:29-44

Smith WA, Mazet JA, Hirsh DC (2002) Salmonella in California wildlife species: prevalence in rehabilitation centers and characterization of isolates. J Zoo Wildl Med 33 228-236

Sohn AH, Probert WS, Glaser CA, Gupta N and others (2003) Human neurobrucellosis with intracerebral granuloma 
caused by a marine mammal Brucella spp. Emerg Infect Dis 9:485-488

Sohn R, Converse K, McLaughlin G (2004) USGS National Wildlife Health Center quarterly wildlife mortality report July 2004 to September 2004. USGS National Wildlife Health Center, Madison, WI. Available at: www.nwhc.usgs.gov/publications/quarterly_reports/ 2004_qtr_3.jsp

Sørum M, Johnsen P, Aasnes B, Rosvoll T, Kruse H, Sundsfjord A, Simonsen G (2006) Prevalence, persistence, and molecular characterization of glycopeptide-resistant Enterococci in Norwegian poultry and poultry farmers 3-8 years after the ban on avoparcin. Appl Environ Microbio 72:516-521

Stamper MA, Gulland FMD, Spraker T (1998) Leptospirosis in rehabilitated Pacific harbor seals from California. J Wildl Dis 34:407-410

Steele CM, Brown RN, Botzler G (2005) Prevalences of zoonotic bacteria among seabirds in rehabilitation centers along the pacific coast of California and Washington, USA. J Wildl Dis 41:735-744

Stegeman JJ, Kloepper-Sams PJ, Farrington JW (1986) Monooxygenase induction and chlorobiphenyls in the deep-sea fish Coryphaenoides armatus. Science 231: 1287-1289

Stoddard R, Gulland F, Atwill E, Lawrence J, Jang S, Conrad P (2005) Salmonella and Campylobacter spp. in Northern Elephant Seals, California. Emerg Infect Dis 11:1967-1969

Tallman J, Sullivan C (2004) Harbor seal (Phoca vitulina) predation on a male harlequin duck (Histrinicus histrionicus). Northwestern Naturalist 85:31-32

Ward PI, Deplazes P, Regli W, Rinder H, Mathis A (2002) Detection of eight Cryptosporidium genotypes in surface and waste waters in Europe. Parasitology 124:359-368

- Warner RE (1968) The role of introduced diseases in the extinction of the endemic Hawaiian avifauna. Condor 70: $101-120$

Webster RG (1998) Influenza: an emerging disease. Emerg Infect Dis 4:436-441

Wolfe ND, Dunavan CP, Diamond J (2007) Origins of major human infectious diseases. Nature 447:279-283

Woodhouse CD, Rennie CJ III (1991) Observations of vaginal calculi in dolphins. J Wildl Dis 27:421-427

Woolhouse ME, Gowtage-Sequeria S (2005) Host range and emerging and reemerging pathogens. Emerg Infect Dis $11: 1842-1847$

Appendix 1. Number of bacterial isolates cultured compared between live, stranded and by-caught marine vertebrates. $\mathrm{N}=$ no. of animals sampled; Total: total isolates

\begin{tabular}{|c|c|c|c|c|c|c|c|c|}
\hline \multirow[t]{2}{*}{ Microorganism } & \multicolumn{3}{|c|}{ Marine mammal } & \multicolumn{3}{|c|}{ Marine bird } & \multirow{2}{*}{$\begin{array}{l}\text { Shark } \\
\text { Caught } \\
(\mathrm{N}=8)\end{array}$} & \multirow[t]{2}{*}{ Total } \\
\hline & $\begin{array}{c}\text { Live } \\
(\mathrm{N}=33)\end{array}$ & $\begin{array}{l}\text { Stranded } \\
(\mathrm{N}=37)\end{array}$ & $\begin{array}{l}\text { By-caught } \\
(\mathrm{N}=16)\end{array}$ & $\begin{array}{c}\text { Live } \\
(\mathrm{N}=54)\end{array}$ & $\begin{array}{l}\text { Stranded } \\
(\mathrm{N}=50)\end{array}$ & $\begin{array}{l}\text { By-caught } \\
\quad(\mathrm{N}=5)\end{array}$ & & \\
\hline \multicolumn{9}{|l|}{ Aerobic Gram-negative bacilli } \\
\hline $\begin{array}{l}\text { Achromobacter (alcaligens) } \\
\text { xylosoxidans ssp. xylosoxidans }\end{array}$ & & & & & 1 & & & 1 \\
\hline $\begin{array}{l}\text { Acinetobacter calcoaceticus- } \\
\text { baumannii }\end{array}$ & & 3 & 4 & & 3 & & 1 & 11 \\
\hline Acinetobacter spp. & 3 & 4 & 4 & 1 & 4 & & & 16 \\
\hline Aeromonas hydrophila & & 1 & & & 6 & & & 7 \\
\hline Aeromonas spp. & & 3 & & 2 & 1 & 2 & & 8 \\
\hline Alcaligenes faecalis & & & & & 1 & & & 1 \\
\hline Burkholderia cepacia & 1 & 1 & & 4 & & & & 6 \\
\hline Chromobacterium spp. & & & & & & & 1 & 1 \\
\hline Chromobacterium violaceum & & 2 & & & & & & 2 \\
\hline Chryseobacterium indologenes & & & 2 & & & & & 2 \\
\hline Citrobacter braaki & 2 & & 1 & 2 & & & 1 & 6 \\
\hline Citrobacter freundii & 1 & 2 & & 5 & 4 & & 2 & 14 \\
\hline Citrobacter koseri & & & & & 1 & & & 1 \\
\hline Citrobacter spp. & & & & 1 & & & & 1 \\
\hline Edwardsiella hoshinae & 1 & 1 & & & & & & 2 \\
\hline Edwardsiella tarda & 4 & 7 & & 1 & & & & 12 \\
\hline Edwardsiella spp. & 1 & & & & 2 & & & 3 \\
\hline Empedobacter brevis & & & & & 1 & & & 1 \\
\hline Enterobacter amnigenus & & & & 3 & & & & 3 \\
\hline Enterobacter cancerigenus & & & & & 1 & & & 1 \\
\hline Enterobacter cloacae & & 2 & 2 & 10 & 5 & 1 & 3 & 23 \\
\hline Enterobacter intermedius & & & & & 1 & & & 1 \\
\hline Enterobacter sakazakii & & & 1 & & & & & 1 \\
\hline Enterobacter avium & & & & & 1 & & & 1 \\
\hline Enterobacter spp. & & 5 & 2 & 12 & 5 & & & 24 \\
\hline Escherichia coli & 33 & 15 & 3 & 51 & 47 & 3 & & 152 \\
\hline Escherichia hermanii & & & & 2 & & & & 2 \\
\hline Escherichia spp. & 1 & & & 5 & 2 & & & 8 \\
\hline Ewingella americana & & 3 & & & & & & 3 \\
\hline
\end{tabular}


Appendix 1. (continued)

\begin{tabular}{|c|c|c|c|c|c|c|c|c|}
\hline \multirow{2}{*}{ Microorganism } & \multicolumn{3}{|c|}{ Marine mammal } & \multicolumn{3}{|c|}{ Marine bird } & \multirow{2}{*}{$\begin{array}{l}\text { Shark } \\
\text { Caught } \\
(\mathrm{N}=8)\end{array}$} & \multirow[t]{2}{*}{ Tota } \\
\hline & $\begin{array}{c}\text { Live } \\
(\mathrm{N}=33)\end{array}$ & $\begin{array}{l}\text { Stranded } \\
(\mathrm{N}=37)\end{array}$ & $\begin{array}{l}\text { By-caught } \\
(\mathrm{N}=16)\end{array}$ & $\begin{array}{l}\text { Live } \\
(\mathrm{N}=54)\end{array}$ & $\begin{array}{l}\text { Stranded } \\
(\mathrm{N}=50)\end{array}$ & $\begin{array}{l}\text { By-caught } \\
(\mathrm{N}=5)\end{array}$ & & \\
\hline Flavimonas odoratum & & & & & 1 & & & 1 \\
\hline Hafnia (Enterobacter) alvei & & 2 & & 8 & & & & 10 \\
\hline Hafnia alvei-doxy sensitive & & & & & & & 1 & 1 \\
\hline Klebsiella oxytoca & & 2 & & 4 & 1 & & & 7 \\
\hline Klebsiella pneumoniae & & 1 & & 8 & 1 & & & 10 \\
\hline Klebsiella ozaenae & & & & 1 & & & & 1 \\
\hline Kluyvera spp. & & 1 & & & & & & 1 \\
\hline Leclercia adecarboxylata & & 2 & 1 & 1 & & 2 & 1 & 7 \\
\hline Moellerella wisconsensis & & 1 & & & 10 & & & 11 \\
\hline Morganella morganii & 2 & 3 & & & 2 & & 1 & 8 \\
\hline $\begin{array}{l}\text { Pantoea (Enterobacter) } \\
\text { agglomerans }\end{array}$ & & 3 & 1 & 2 & 3 & 2 & & 11 \\
\hline Pasteurella multocida & & & & & 3 & & & 3 \\
\hline Pasteurella spp. & & & & & 1 & & & 1 \\
\hline Pasteurella spp. (not P. multocida) & & & & & 1 & & & 1 \\
\hline Photobacterium damsela & 4 & 4 & & & & & & 8 \\
\hline Plesiomonas shigelloides & & 1 & & 2 & 1 & & & 4 \\
\hline Proteus mirabilis & 1 & 3 & & 16 & 5 & & & 25 \\
\hline Proteus penneri & & & & 1 & 1 & & & 2 \\
\hline Proteus vulgaris & & 1 & & & 1 & & & 2 \\
\hline Providencia rettgeri & & & & & & 2 & & 2 \\
\hline Povidencia stuartii & & 1 & & & & & & 1 \\
\hline $\begin{array}{l}\text { Pseudomonas (flavimonas) } \\
\text { oryzihabitans }\end{array}$ & & 1 & & 1 & 1 & & & 3 \\
\hline Pseudomonas aeruginosa & 1 & & & & 1 & & 3 & 5 \\
\hline Pseudomonas spp. & 3 & 13 & 4 & 10 & 13 & 2 & 1 & 46 \\
\hline Pseudomonas stutzeri & & 1 & & & & & & 1 \\
\hline Salmonella spp. & & & & 1 & & & & 1 \\
\hline Serratia liquefaciens & & 1 & & 11 & 4 & & & 16 \\
\hline Serratia marcesens & & 5 & & 1 & & 1 & & 7 \\
\hline Serratia spp. & & & & 1 & & & & 1 \\
\hline Shewanella algae & & & & & 14 & & & 14 \\
\hline Shewanella spp. & 1 & 16 & & 1 & 10 & 2 & 2 & 32 \\
\hline Sphingomonas multivorium & & & 1 & & & & & 1 \\
\hline Sphingomonas paucimobilis & & 2 & & 1 & 1 & & & 4 \\
\hline Sphingomonas spp. & & & & 1 & & & & 1 \\
\hline Stenotrophomonas maltophilia & & 2 & 1 & & 1 & & 1 & 5 \\
\hline Vibrio alginolyticus & & 2 & & & 8 & & & 10 \\
\hline Vibrio cholerae & & & & & 1 & & & 1 \\
\hline Vibrio fluvialis & & 1 & & & & & & 1 \\
\hline Vibrio parahaemolyticus & & 2 & & 8 & & & & 10 \\
\hline Vibrio spp. & & 3 & & & & 2 & & 5 \\
\hline Yersinia ruckeri & & & & 1 & & & & 1 \\
\hline Aerobic Gram-negative coccobacill & & & & & & & & \\
\hline Campylobacter spp. & & & & 1 & & & & 1 \\
\hline Aerobic Gram-positive bacilli & & & & & & & & \\
\hline Bacillus spp. & 1 & 5 & & 2 & 3 & & & 11 \\
\hline Corynebacterium aquaticum & & 1 & & & & & & 1 \\
\hline Corynebacterium spp. & & 4 & 1 & 6 & 3 & & & 14 \\
\hline Aerobic Gram-positive cocci & & & & & & & & \\
\hline Enterococcus avium & & & & 1 & & & & 1 \\
\hline Enterococcus faecalis & & & & 3 & & & & 3 \\
\hline Enterococcus spp. & 3 & 9 & 1 & 15 & 14 & 1 & & 43 \\
\hline Staphlococcus coagulase positive & & 2 & 2 & & 5 & & & 9 \\
\hline Staphlococcus spp. & & 2 & & 1 & & & & 3 \\
\hline Staphlococcus-hemolytic & 1 & & & & & & & 1 \\
\hline $\begin{array}{l}\text { Staphlycoccus coagulase } \\
\text { negative-non-hemolytic }\end{array}$ & & 5 & 4 & 4 & 3 & & & 16 \\
\hline Staphylococcus-non-hemolytic & & & & 7 & & & & 7 \\
\hline
\end{tabular}


Appendix 1. (continued)

\begin{tabular}{|c|c|c|c|c|c|c|c|c|}
\hline \multirow[t]{2}{*}{ Microorganism } & \multicolumn{3}{|c|}{ Marine mammal } & \multicolumn{3}{|c|}{ Marine bird } & \multirow{2}{*}{$\begin{array}{c}\text { Shark } \\
\text { Caught } \\
(\mathrm{N}=8)\end{array}$} & \multirow[t]{2}{*}{ Total } \\
\hline & $\begin{array}{c}\text { Live } \\
(\mathrm{N}=33)\end{array}$ & $\begin{array}{c}\text { Stranded } \\
(\mathrm{N}=37)\end{array}$ & $\begin{array}{l}\text { By-caught } \\
(\mathrm{N}=16)\end{array}$ & $\begin{array}{c}\text { Live } \\
(\mathrm{N}=54)\end{array}$ & $\begin{array}{l}\text { Stranded } \\
(N=50)\end{array}$ & $\begin{array}{l}\text { By-caught } \\
(\mathrm{N}=5)\end{array}$ & & \\
\hline Streptococcus-alpha & & 3 & 2 & 3 & 9 & & & 17 \\
\hline Streptococcus-beta hemolytic & & 2 & 4 & & & & & 6 \\
\hline Streptococcus-gamma & & & & 10 & & & & 10 \\
\hline \multicolumn{9}{|l|}{ Anaerobic Gram-positive bacilli } \\
\hline Actinomyces spp. & 1 & & & & & & & 1 \\
\hline Brevibacterium spp. & & 1 & & & & & 1 & 2 \\
\hline Clostridium bifermentans & 1 & 1 & & & & & & 2 \\
\hline Clostridium perfringens & 8 & 7 & & 4 & 12 & & & 31 \\
\hline Clostridium spp. & 8 & 3 & & & 1 & & & 12 \\
\hline Propioibacterium acne & & 1 & & & & & & 1 \\
\hline \multicolumn{9}{|l|}{ Anaerobic Gram-negative baccili } \\
\hline Bacteroides spp. & 2 & 1 & & 1 & 2 & & & 6 \\
\hline \multicolumn{9}{|l|}{ Anaerobic Gram-positive cocci } \\
\hline Peptostreptococcus spp. & & 3 & & & & & & 3 \\
\hline Total & 84 & 173 & 41 & 237 & 223 & 20 & 19 & 797 \\
\hline
\end{tabular}

Appendix 2. Diversity and number of bacterial and fungal isolates cultured in routine sites from live, stranded and by-caught marine vertebrates. $\mathrm{N}=$ no. of individuals sampled at each routine swab site; Total: total isolates

\begin{tabular}{|c|c|c|c|c|c|c|}
\hline Microorganism & $\begin{array}{l}\text { Fecal/cloaca } \\
\qquad(\mathrm{N}=129)\end{array}$ & $\begin{array}{l}\text { Coelom } \\
(\mathrm{N}=35)\end{array}$ & $\begin{array}{l}\text { Abdomen } \\
(\mathrm{N}=42)\end{array}$ & $\begin{array}{l}\text { Thorax } \\
(\mathrm{N}=38)\end{array}$ & $\begin{array}{l}\text { Oral/nares/blow } \\
(\mathrm{N}=52)\end{array}$ & Total \\
\hline \multicolumn{7}{|l|}{ Aerobic Gram-negative bacilli } \\
\hline $\begin{array}{l}\text { Achromobacter (alcaligens) } \\
\text { xylosoxidans ssp. xylosoxidans }\end{array}$ & & & & & 1 & 1 \\
\hline Acinetobacter calcoaceticus-baumannii & & 3 & 1 & 2 & 2 & 8 \\
\hline Acinetobacter spp. & 4 & & 4 & 3 & 4 & 15 \\
\hline Aeromonas hydrophilia & 2 & & & & 4 & 6 \\
\hline Aeromonas spp. & 2 & 2 & & & 7 & 11 \\
\hline Alcaligenes faecalis & 1 & & & & & 1 \\
\hline Burkholderia cepacia & 3 & & & 1 & 3 & 7 \\
\hline Chryseobacterium indologenes & & & & 2 & & 2 \\
\hline Chromobacterium spp. & & & & & 1 & 1 \\
\hline Citrobacter braakii & 5 & & & & & 5 \\
\hline Citrobacter freundii & 3 & & & & 6 & 9 \\
\hline Citrobacter koseri & & & & & 1 & 1 \\
\hline Citrobacter spp. & 1 & & & & & 1 \\
\hline Edwardsiella hoshinae & 1 & & & 1 & & 2 \\
\hline Edwardsiella spp. & 3 & 1 & & & & 4 \\
\hline Edwardsiella tarda & 5 & & 3 & 3 & 1 & 12 \\
\hline Enterobacter amnigenus & 3 & & & & & 3 \\
\hline Enterobacter avian & 1 & & & & & 1 \\
\hline Enterobacter cancerigenus & & & & & 1 & 1 \\
\hline Enterobacter cloacae & 12 & 1 & & 2 & 6 & 21 \\
\hline Enterobacter intermedius & 1 & & & & & 1 \\
\hline Enterobacter spp. & 5 & 2 & & 2 & 6 & 15 \\
\hline Escherichia coli & 107 & 4 & 3 & 8 & 20 & 142 \\
\hline Escherichia hermanii & 2 & & & & & 2 \\
\hline Escherichia spp. & 5 & 2 & & & & 7 \\
\hline Ewingella americana & & & & & 2 & 2 \\
\hline Flavimonas odoratum & & & & & 1 & 1 \\
\hline Hafnia alvei & 7 & & 1 & & 4 & 12 \\
\hline Klebsiella oxytoca & 3 & & & & 1 & 4 \\
\hline Klebsiella ozaenoe & 1 & & & & & 1 \\
\hline Klebsiella pneumoniae & 6 & 1 & & 1 & 5 & 13 \\
\hline Leclercia adecarboxylata & 1 & 2 & & 1 & & 4 \\
\hline Moellerella wisconsensis & 2 & 1 & & & 5 & 8 \\
\hline
\end{tabular}


Appendix 2. (continued)

\begin{tabular}{|c|c|c|c|c|c|c|}
\hline Microorganism & $\begin{array}{l}\text { Fecal/cloaca } \\
\quad(\mathrm{N}=129)\end{array}$ & $\begin{array}{l}\text { Coelom } \\
(\mathrm{N}=35)\end{array}$ & $\begin{array}{l}\text { Abdomen } \\
(\mathrm{N}=42)\end{array}$ & $\begin{array}{l}\text { Thorax } \\
(\mathrm{N}=38)\end{array}$ & $\begin{array}{l}\text { Oral/nares/blow } \\
\qquad(\mathrm{N}=52)\end{array}$ & Total \\
\hline Morganella morganii & & & & & 1 & 1 \\
\hline Pantoea agglomerans & 3 & 2 & & 2 & 2 & 9 \\
\hline Pasteurella multocida & & & & & 3 & 3 \\
\hline Pasteurella spp. (not multocida) & & & & & 1 & 1 \\
\hline Photobacterium damselae & 4 & & 1 & 2 & & 7 \\
\hline Plesiomonas shigelloides & 2 & & & & 1 & 3 \\
\hline Proteus mirabilis & 6 & & 2 & 2 & 8 & 18 \\
\hline Proteus penneri & & & & & 2 & 2 \\
\hline Proteus vulgaris & 1 & & & & 2 & 3 \\
\hline Providencia rettgeri & 2 & & & & & 2 \\
\hline Pseudomonas aeruginosa & 2 & & & & & 2 \\
\hline Pseudomonas (flavimonas) oryzihabitans & & & & & 1 & 1 \\
\hline Pseudomonas spp. & 17 & 9 & 2 & 5 & 14 & 47 \\
\hline Pseudomonas stutzeri & & & & & 1 & 1 \\
\hline Salmonella spp. & & & & & 1 & 1 \\
\hline Serratia liquefaciens & 3 & & & & 9 & 12 \\
\hline Serratia marcesens & 1 & & 1 & 2 & 1 & 5 \\
\hline Serratia spp. & & & & & 1 & 1 \\
\hline Shewanella algae & 3 & & & & 6 & 9 \\
\hline Shewanella spp. & 7 & 4 & 1 & 3 & 7 & 22 \\
\hline Sphingomonas multivorium & & & & 1 & & 1 \\
\hline Sphingomonas paucimobilis & 1 & & 1 & & 2 & 4 \\
\hline Stenotrophomonas maltophilia & & 1 & & 2 & & 3 \\
\hline Vibrio alginolyticus & 6 & 1 & & & 9 & 16 \\
\hline Vibrio cholerae & & & & & 1 & 1 \\
\hline Vibrio parahaemolyticus & 3 & 2 & & & 1 & 6 \\
\hline Vibrio spp. & & & 2 & 2 & 1 & 5 \\
\hline Yersinia ruckeri & & 1 & & & & 1 \\
\hline \multicolumn{7}{|l|}{ Aerobic Gram-negative coccobacilli } \\
\hline Campylobacter spp. & 2 & & & & & 2 \\
\hline \multicolumn{7}{|l|}{ Aerobic Gram-positive bacilli } \\
\hline Bacillus spp. & 2 & & 1 & & 5 & 8 \\
\hline Corynebacterium aquaticum & & & & 1 & & 1 \\
\hline Corynebacterium spp. & 4 & & 3 & & 4 & 11 \\
\hline \multicolumn{7}{|l|}{ Aerobic Gram-positive cocci } \\
\hline Enterococcus avian & 1 & & & & & 1 \\
\hline Enterococcus faecalis & 3 & & & & & 3 \\
\hline Enterococcus spp. & 29 & 3 & 4 & 5 & 12 & 53 \\
\hline Staphlococcus coagulase positive & 3 & 1 & 1 & 1 & & 6 \\
\hline Staphlococcus-hemolytic & 1 & & & & & 1 \\
\hline Staphylococcus-non-hemolytic & & & & & 7 & 7 \\
\hline $\begin{array}{l}\text { Staphlycoccus-non-hemolytic } \\
\text { coagulase negative }\end{array}$ & 1 & 1 & 5 & 3 & 1 & 11 \\
\hline Streptococcus-gamma & 1 & & & & 9 & 10 \\
\hline Streptococcus-alpha & 4 & & 1 & 1 & 7 & 13 \\
\hline Streptococcus-beta hemolytic & & & 3 & 2 & & 5 \\
\hline \multicolumn{7}{|l|}{ Anaerobic Gram-positive bacilli } \\
\hline Actinomyces spp. & & 1 & & 1 & & 2 \\
\hline Clostridium bifermens & 1 & & 1 & & & 2 \\
\hline Clostridium perfringens & 17 & 1 & 1 & 1 & 4 & 24 \\
\hline Clostridium spp. & 8 & & & 2 & & 10 \\
\hline Propioibacterium acnes & & & 2 & & & 2 \\
\hline \multicolumn{7}{|l|}{ Anaerobic Gram-negative baccili } \\
\hline Bacteroides spp. & 3 & & & & 2 & 5 \\
\hline \multicolumn{7}{|l|}{ Anaerobic Gram-positive cocci } \\
\hline Peptostreptococcus spp. & & & 1 & & 1 & 2 \\
\hline \multicolumn{7}{|l|}{ Fungi } \\
\hline Aspergillus spp. & & 1 & & 1 & & 2 \\
\hline Total & 327 & 47 & 45 & 65 & 208 & 692 \\
\hline Mean per swab & 2.5 & 1.3 & 1.1 & 1.7 & 4 & \\
\hline
\end{tabular}




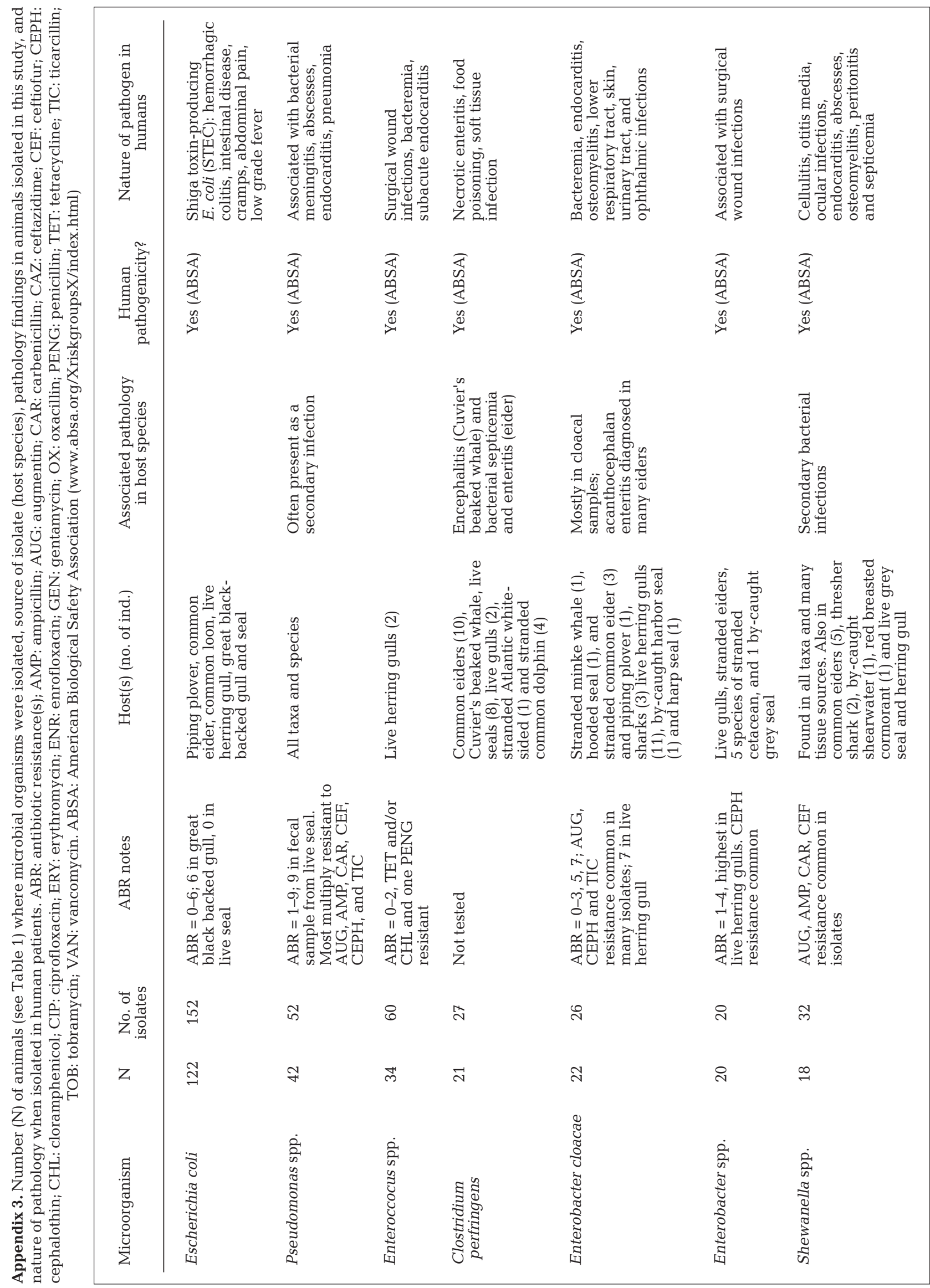




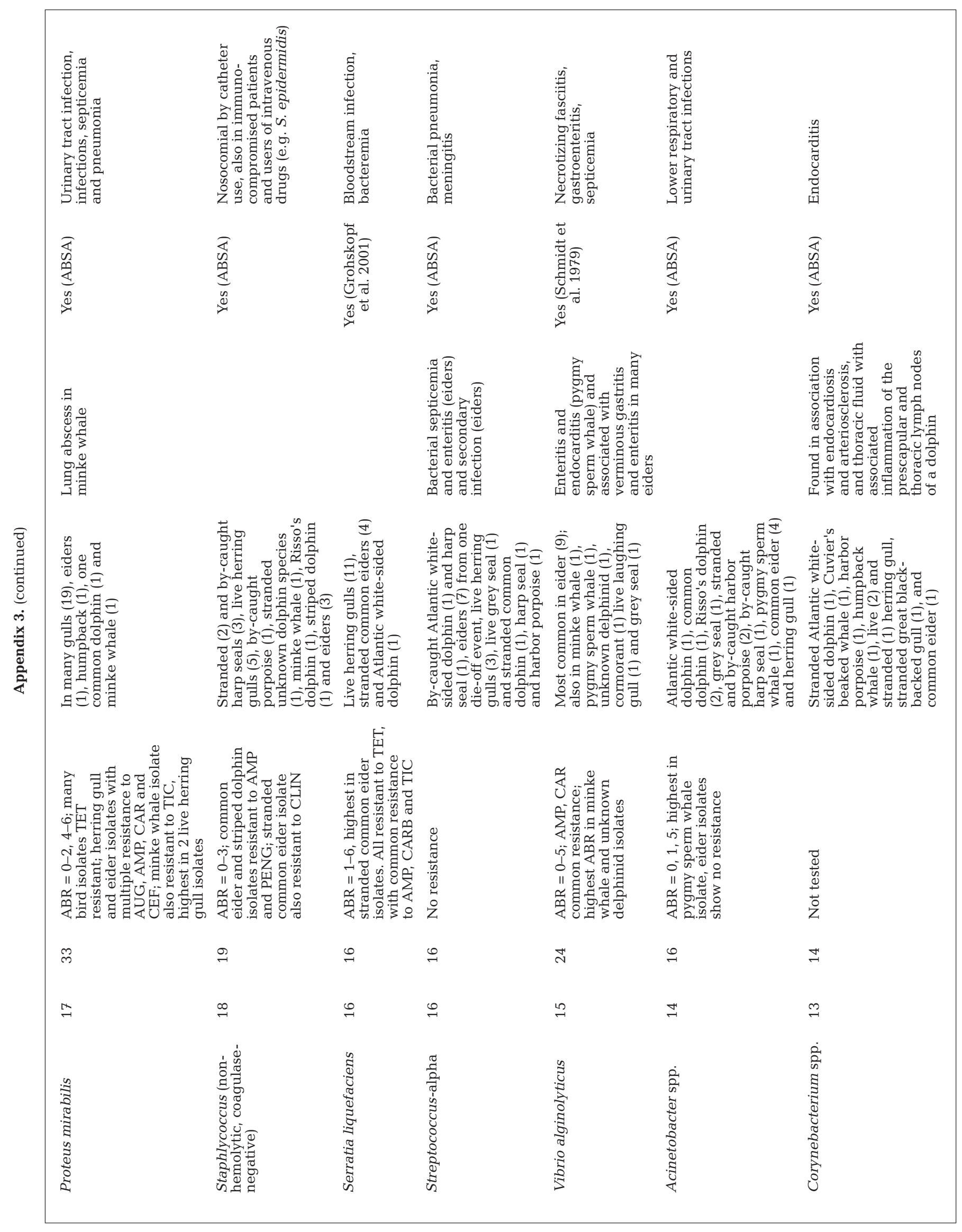




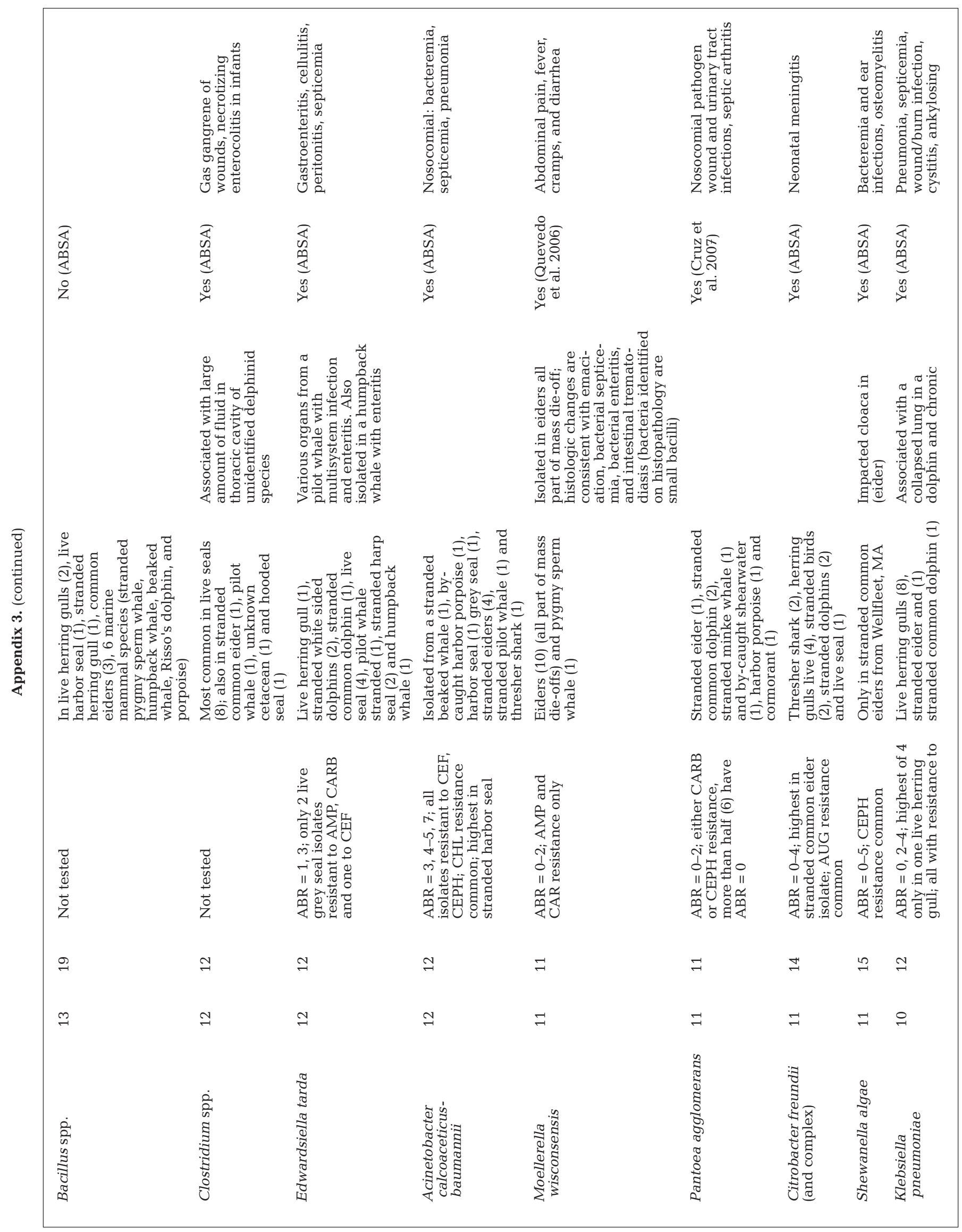



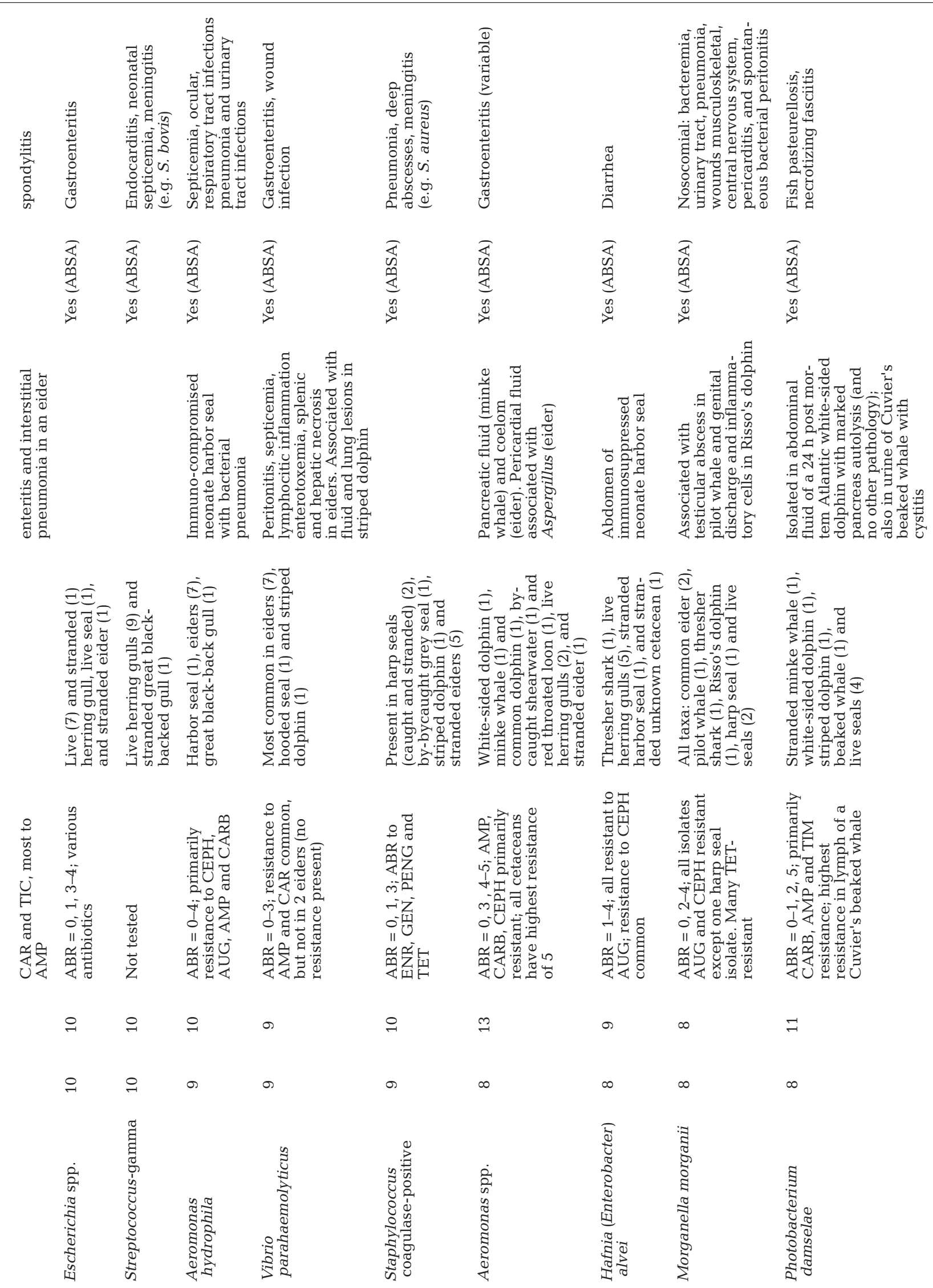


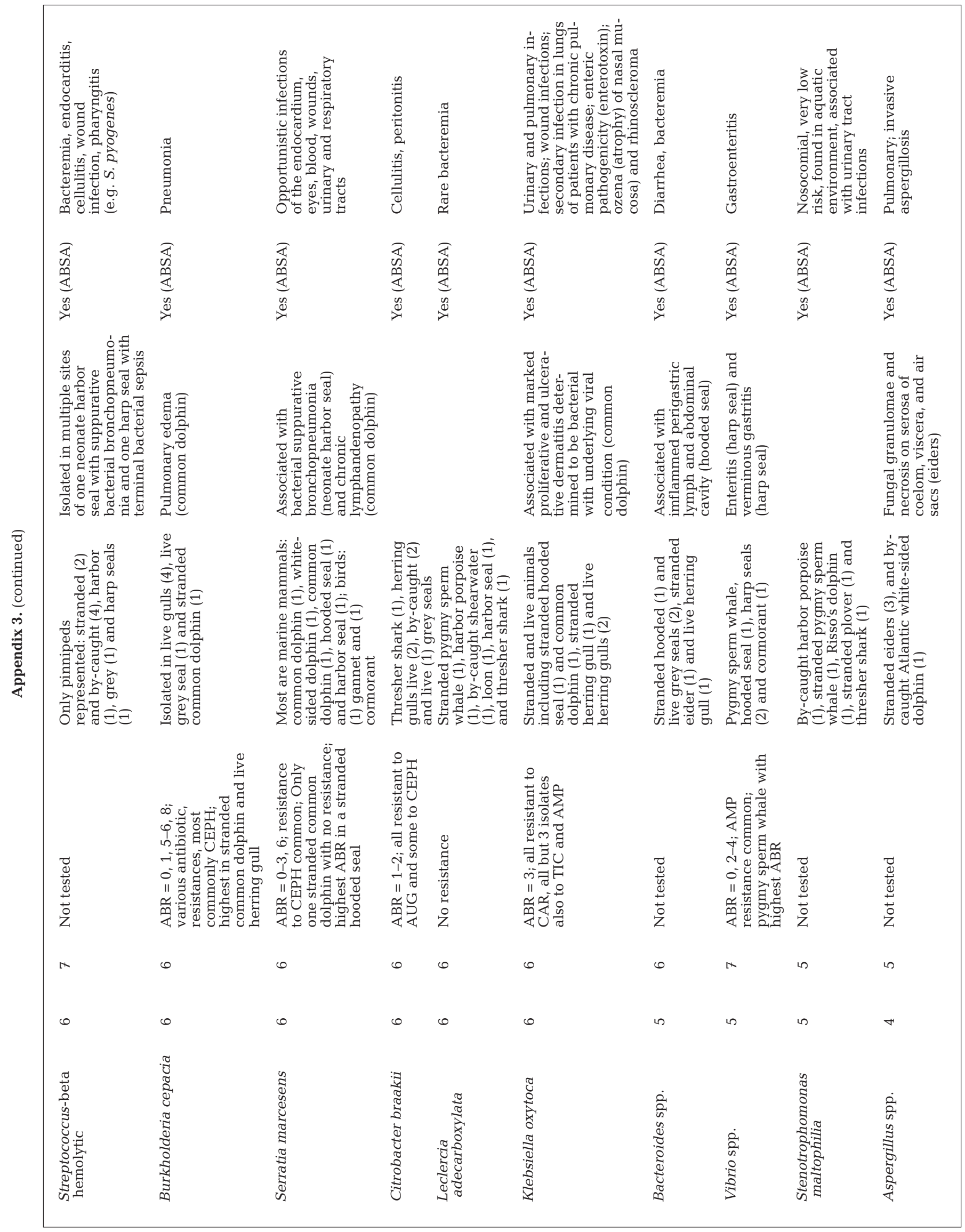




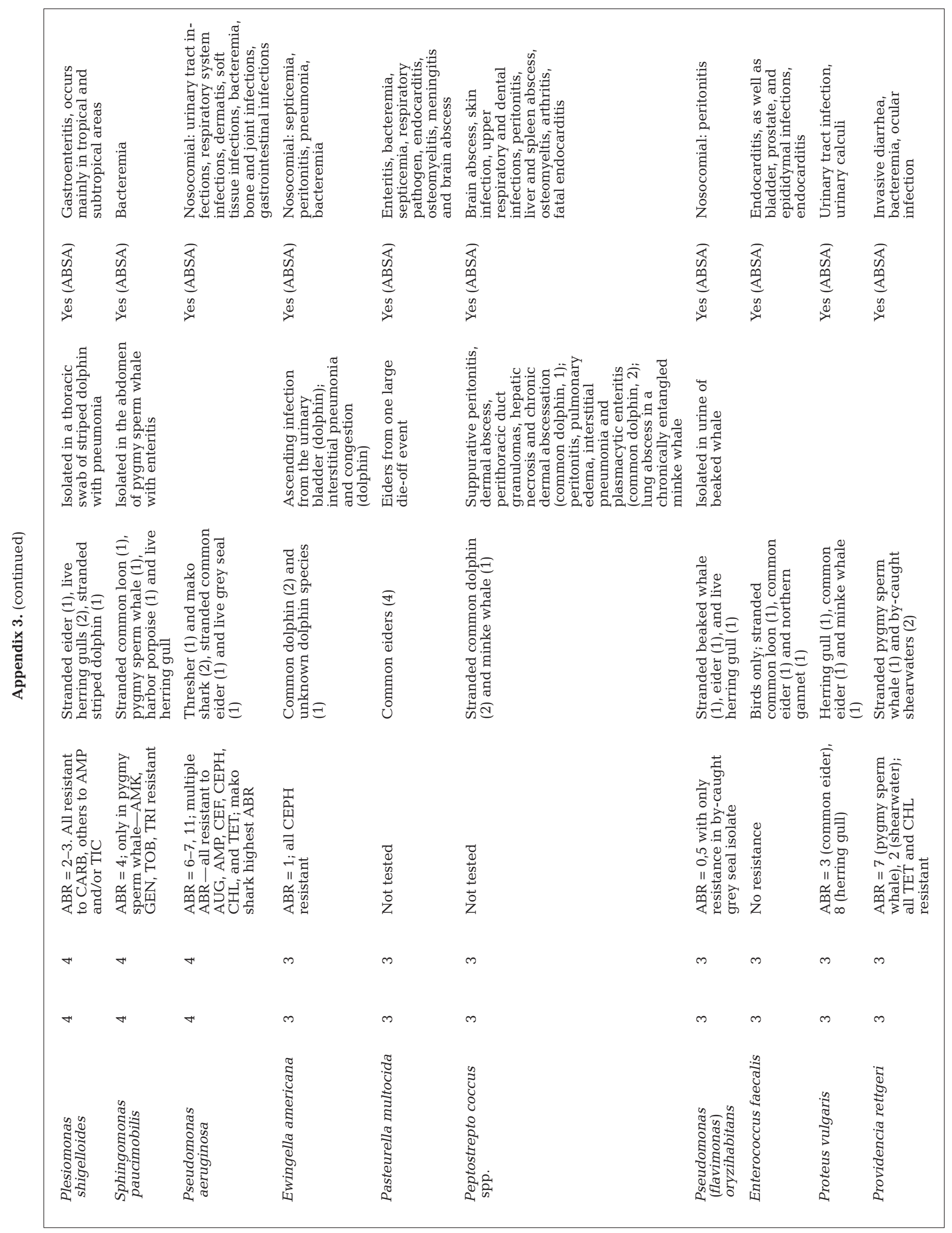




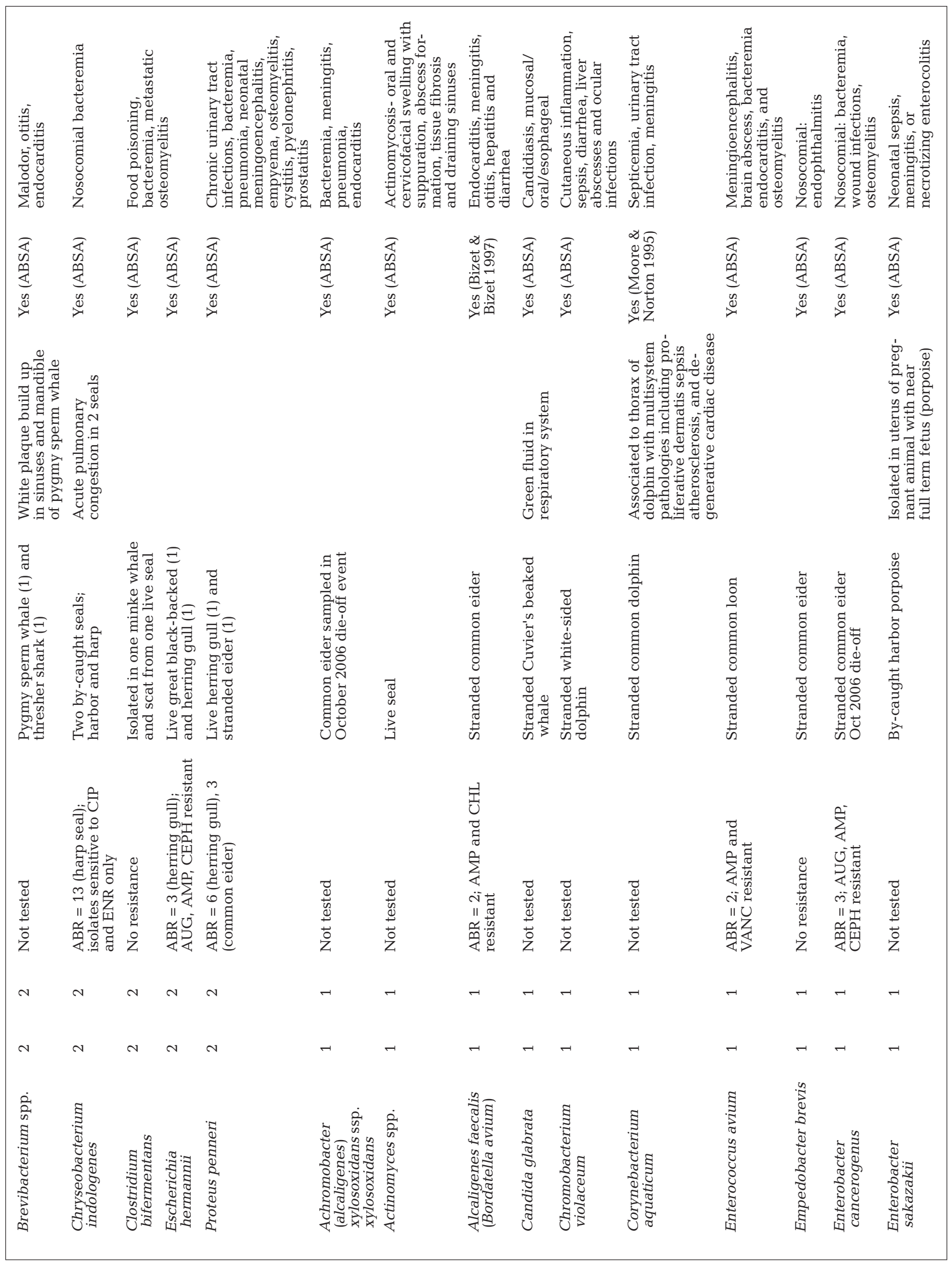




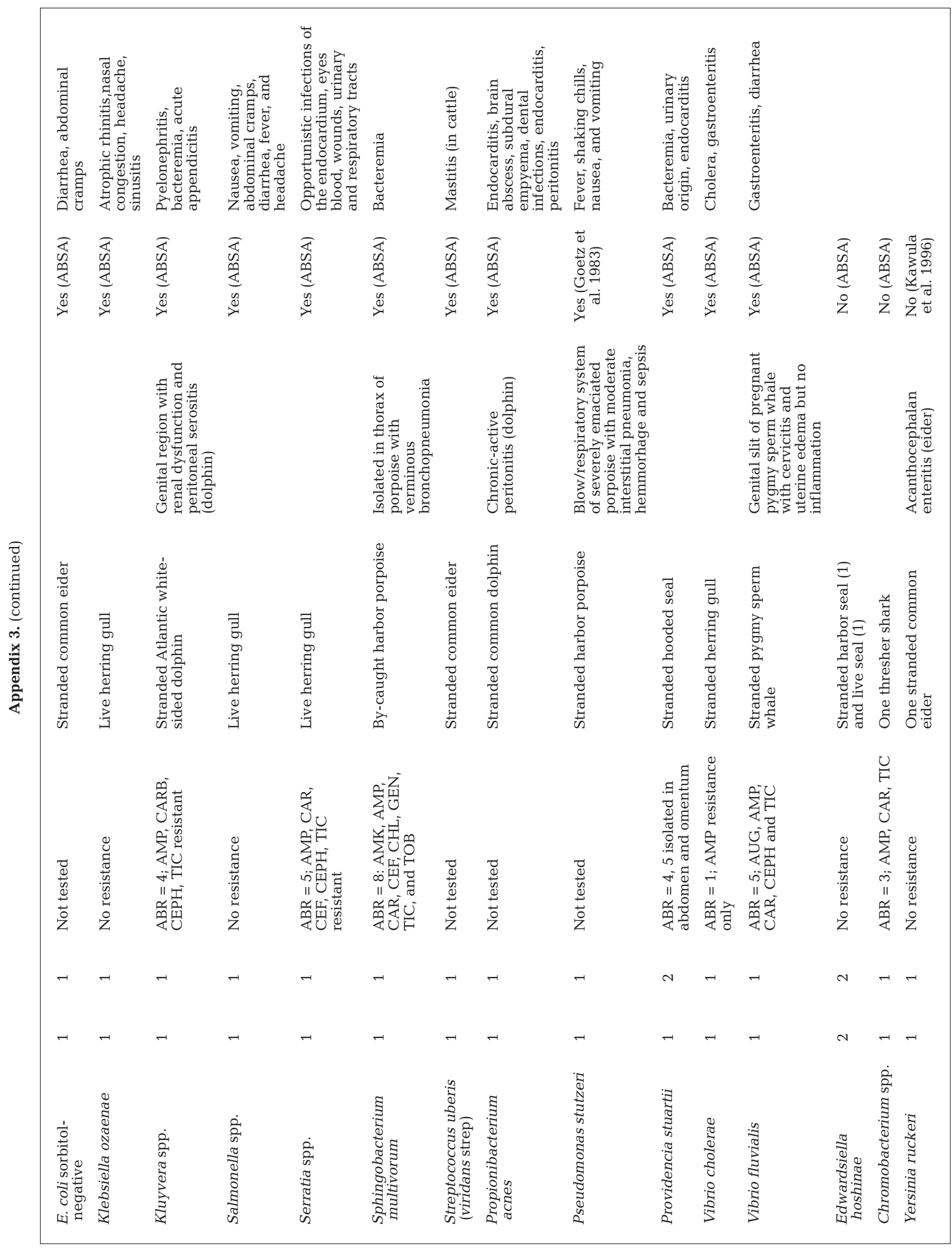

